\title{
Inflation persistence and exchange rate regime: Implications for dynamic adjustment to shocks in a small open economy
}

\author{
Karlygash Kuralbayeva* \\ Lincoln College, University of Oxford
}

July 11, 2007

\begin{abstract}
The paper examines implications of inflation persistence for business cycle dynamics following terms of trade shock in a small open economy, under fixed and flexible exchange rate regimes. It is shown that the country's adjustment paths are slow and cyclical if there is a significant backward-looking element in the inflation dynamics and the exchange rate is fixed. It is also shown that such cyclical adjustment paths are moderated if there is a high proportion of forward-looking price setters. In contrast, with an independent monetary policy, flexible exchange rate allows to escape severe cycles.
\end{abstract}

JEL Classifications: E32, F40, F41

Keywords: inflation inertia, exchange rate regimes, persistence, Phillips curve, small open economy

\footnotetext{
*Address: Lincoln College, Turl Street, OX13DR, Oxford, UK, email: karlygash.kuralbayeva@lincoln.ox.ac.uk, phone: + 44 7775521080, fax: +44 1865271094 . I am indebted to David Vines for helpful comments and guidance. I am thankful to Florin Bilbiie for many helpful comments at different stages. I also benefited from comments from Tatiana Kirsanova, Richard Mash, Christopher Adam and Rick van der Ploeg as well as conference and seminar participants at the Gorman workshop (University of Oxford), XV International "Tor Vergata" conference on Banking and Finance, University of Rome "Tor Vergata", 11th International Conference on Macroeconomic Analysis and International Finance. The paper has been awarded as the best young economist paper presented at the "Tor Vergata" conference. All errors are mine.
} 


\section{Introduction}

New Keynesian macroeconomics ${ }^{1}$, the modern approach featuring rational expectations and some form of microfoundations has become the main workhorse framework in modern monetary policy analysis. The essential macroeconomic feature of the New Keynesian macroeconomics is the absence of instantaneous market clearing, which is rationalized by the assumption of price rigidity. In the New Keynesian model, prices fail to adjust rapidly to clear markets within short period of time, so there can be periods when aggregate output is different from its so-called potential level, and monetary policy can have short-run effects on economic activity. Thus, price stickiness and so price-setting behaviour is the essence of New Keynesian macroeconomics, which have been modeled in many different ways. Seminal papers by Fisher (1977), Taylor (1980), Calvo (1983) and Mankiw (1985) present some well-known examples of modeling price inertia from the price-setting behaviour of firms. Price setting behaviour approach within a general equilibrium framework has resulted in a derivation of the New Keynesian Phillips Curve (NKPC), which describes the process of inflation and relates it to a level of economic activity within New Keynesian models.

However, New Keynesian Phillips Curve has been severely criticized, mostly on empirical grounds. The most relevant to the discussions in this paper critique of the NKPC is persistence problem $^{2}$, that is failure of the NKPC generate the degree of inflation persistence observed in the data. ${ }^{3}$ The origin of this problem is forward-looking nature of the $\mathrm{NKPC}^{4}$ where inflation today

\footnotetext{
${ }^{1}$ See Gordon (1990) for discussion of New Keynesian economics.

${ }^{2}$ Other critiques of the NKPC include the following. First, models using the NKPC have counterfactual prediction that a fully credible disinflation can cause an economic boom. (Ball (1994), Mankiw (2001)). Second, the NKPC fails to generate empirically plausible impulse response functions to monetary policy shocks (Mankiw (2001)). While, monetary shocks should have a delayed and gradual effect on inflation in actual data, the NKPC inflation can adjust immediately to changes in monetary policy. This also in odds with the real world, where nominal shocks appear to have their greatest effect on inflation only after they have their effect on real activity. Third, in addition to inability of the NKPC to generate the observed persistence in inflation, it also fails to produce real output persistence (Chari et al. (2000)).

${ }^{3}$ See for example, Fuhrer and Moore (1995), Galí and Gertler (1999), Benigno and Lopez-Salido (2002), and Mehra (2004).

${ }^{4}$ whether it is derived from Taylor (1980) or Calvo (1983) pricing mechanisms. The Calvo price-setting mechanism has been the most commonly used in the New Keynesian models because of its analytical tractability.
} 
depends on the sequence of expected future output gaps. This implies that there is no structural relationship between current and lagged inflation, and all persistence in inflation comes from the persistence in the output-gap term.

These observations about the NKPC have motivated many researches to develop theoretical models which introduce inflation persistence. ${ }^{5}$ In the micro-founded way the literature suggests two main mechanisms. First is an introduction of a rule-of-thumb price setting behaviour by some firms (Galí and Gertler (1999), Steinsson (2003)). The second mechanism is a backwardlooking price indexation (Christiano et al. (2001), Smets and Wouters (2002)). As an alternative to micro-founded mechanisms, inflation inertia can be modeled on the basis of adaptive expectations as in Roberts (1997), on the basis of sticky information as in Mankiw and Reis (2001), or as a signal extraction problem in Erceg and Levin (2003).

The insights about the New Keynesian Phillips Curve have also spawned a large empirical literature aimed to investigate the empirical evidence for inflation persistence, its determinants, implications for monetary policy and patterns of price setting at micro level. Thus, comprehensive empirical research in the euro area has been performed by the Eurosystem Inflation Persistence Network (see Angeloni et al. (2004) for summary). Various empirical studies, by using US data, have also emerged recently (Bils and Klenow (2004), Nakamura and Steinsson $(2006))$.

Yet, despite the growing literature on the inflation persistence, the implications of inflation persistence for business cycle dynamics in an open economy need to be fully analyzed.

This paper therefore seeks to examine how inflation inertia shapes the dynamics of adjustment to external shocks in a small open economy, and how it is affected by the choice of exchange rate regime. With this aim, I develop a dynamic general equilibrium small open-economy model, where inflation persistence is incorporated via introduction of rule-of-thumb price setting behaviour. I use this model to study the effects of such backward-looking behaviour on dynamic adjustment in response to terms-of-trade shock. I perform the analysis under two exchange rate regimes, a fixed rate and a flexible exchange rate. Inflation in the model is governed by a Phillips

\footnotetext{
${ }^{5}$ Some research from the late 1990s has disregarded the forward-looking term in the Phillips curve and focused on entirely backward-looking specification of the curve (see for example Svensson (1997) and Rudebusch and Svensson (1999)). However this research is not set in a micro-founded framework.
} 
curve, that can be either backward-looking (accelerationist), forward-looking (New Keynesian) or hybrid. In this paper I deliberately focus on two limiting specifications of the Phillips curve: almost forward-looking specification and almost backward-looking Phillips curve. This allows me to examine how backward-looking behaviour changes the propagation of the shocks to the economy compared with a forward-looking specification, which has been extensively studied in the literature on monetary policy.

So, this study focuses on analysis how the backward-looking behaviour affects the responses of the economy to the shock under fixed and flexible exchange rates. This study does not attempt to evaluate whether one exchange rate regime would be potentially beneficial than the other, when the economy exhibits significant degree of inflation inertia. Neither does this study examine the question of optimal monetary policy (optimal interest rate rule) and no attempt is made to derive 'optimal' feedback parameters in the interest rate rules, conditional on the degree of forward-lookiness in the Phillips curve. ${ }^{6}$

It is well-known that under a fixed exchange rate regime, monetary authority loses the domestic interest rate as an instrument of monetary policy and country's real interest rate would no longer play the role of primary adjustment mechanism. Moreover, as I show in this paper, the real interest rate generates a destabilizing effect ${ }^{7}$ in the economy in response to the positive demand shock if there is a significant backward-looking element in inflation dynamics. This occurs because a positive demand shock, stemming from an improvement in the terms of trade, causing an increase in domestic inflation, decreases the real interest rate, which causes further output gains and exacerbates inflation, so this is potentially destabilizing. The destabilizing effect of the real interest rate is aggravated with a higher proportion of rule-of-thumb price setters. However, it does not cause instability in the system, as there is a dominating stabilizing real exchange rate channel, which outweighs the destabilizing feature of the real interest rate movements under the fixed exchange rate. Another essential point about the real exchange rate aspect of the adjustment process is that the real exchange rate carries out the burden of adjustment to the shock. In contrast, under independent monetary policy, the nominal exchange

\footnotetext{
${ }^{6}$ There are papers which analyze optimal monetary policy in an economy with inflation persistence (although they mostly focus on a closed economy, one-sector set-up without capital). For overview of this research, see Levin and Moessner (2005).

${ }^{7}$ The destabilizing real interest rate effect first has been notied by Wicksell (1907).
} 
rate facilitates adjustment to the shock, serving as a 'shock absorber'.

Because of these differences in adjustment mechanisms under fixed exchange rate compared with a flexible exchange rate, the dynamic path of the real exchange rate exhibits cyclical behaviour compared with the smooth response under flexible exchange rate. The extent of 'cyclicality' depends on the nature of the inflation process. If inflation is 'backward-looking' then the real exchange rate and the economy exhibit cyclical behaviour. If, however, inflation is 'forward-looking' then the real exchange rate's path as well as economy's path is hump-shaped.

The reminder of the paper is structured as follows. Section 2 describes the model and defines a competitive equilibrium for the economy. Section 3 discusses calibration of the model. I discuss the simulation results in section 4 . Section 5 concludes.

\section{Model of a Small Open Economy}

I consider a two-sector dynamic stochastic general equilibrium model with nominal rigidities. The domestic economy is open and small and comprises three sectors: traded, non-traded goods, and the oil sector. It is assumed that oil production requires no domestic factor inputs, and all of its production is exported. The exogenous price of oil is subject to stochastic shocks. The model assumes flexible price traded goods, which are traded in competitive markets, and a continuum of monopolistically produced non-traded goods. I assume Calvo-type price stickiness in the non-traded sector. I also allow for some additional inflation inertia, using a rule-ofthumb price setting mechanism outlined in Steinsson (2003). Domestic households consume both non-traded and traded goods. Traded are also invested and could be imported from the rest of the world. Non-traded goods are also used to meet capital installation costs, which are a composite of both non-traded and traded goods in the same mix as the household's consumption basket. Households own production firms, supply labor and accumulate capital that they rent to production firms. As the owners of the firms producing non-traded goods, households also receive the income corresponding to the monopolistic rents generated by these firms. Non-traded goods firms produce differentiated varieties of non-traded goods. I consider two alternative monetary policy regimes: flexible and fixed exchange rate regimes. In both cases the monetary authority uses the nominal interest rate as a policy instrument and monetary policy is modeled through 
an interest rate rule.

\subsection{Consumers}

The economy is inhabited by a continuum of households with mass 1 . The representative consumer has preferences given by:

$$
U=E_{0} \sum_{t=0}^{\infty} \beta^{t} u\left(C_{t}, H_{t}\right)
$$

where $C_{t}$ is a composite consumption index and $H_{t}$ is the labor supply. We assume the following functional form of utility function $u$ :

$$
u=\frac{C_{t}^{1-\sigma}}{1-\sigma}-\eta \frac{H^{1+\psi}}{1+\psi}
$$

Composite consumption is a constant-elasticity-of-substitution (CES) function of traded goods and non-traded goods, with

$$
C_{t}=\left[a^{\frac{1}{\rho}} C_{N, t}^{(\rho-1) / \rho}+(1-a)^{\frac{1}{\rho}} C_{T, t}^{(\rho-1) / \rho}\right]^{\rho /(1-\rho)}, \rho>0, .
$$

with $C_{N, t}$ and $C_{T, t}$ being indexes of consumption of non-traded and traded goods respectively. Under such specification of the composite consumption function, the parameter $\sigma$ measures the (inverse) intertemporal elasticity of substitution and the parameter $\rho$ is the intratemporal elasticity of substitution between non-traded and traded goods. The implied consumer price index is then

$$
P_{t}=\left[a P_{N, t}^{1-\rho}+(1-a) P_{T, t}^{1-\rho}\right]^{\frac{1}{1-\rho}}
$$

where $P_{N, t}$ is the price index of the composite differentiated non-traded good, $P_{T, t}$ is the price of flexible-price traded good, expressed in national currency, and $P_{t}$ is the consumer price index. ${ }^{8}$ Indexes of consumption of non-traded goods, in turn, is given by CES aggregators of the quantities consumed of each variety, with elasticity of substitution across different categories equal

\footnotetext{
${ }^{8}$ The price index $P_{t}$ is the minimum expenditure required to purchase one unit of aggregate consumption good $C_{t}$. For the derivation see, for example, Obstfeld and Rogoff (2002).
} 
to $\lambda$ :

$$
C_{N t}=\left(\int_{0}^{1} C_{N, t}(j)^{\frac{\lambda-1}{\lambda}} d j\right)^{\frac{\lambda}{\lambda-1}}, \text { with } \lambda>1
$$

where $C_{N, t}(j)$ is consumption of variety $j$ by the representative household. When $\lambda$ tends to infinity all varieties are perfect substitutes for each other. The price of variety $j$ is denoted $P_{N, t}(j)$, and the price of a consumption basket of non-traded goods $P_{N, t}$ is defined as a CES index ${ }^{9}$ with elasticity $1 / \lambda$ :

$$
P_{N, t}=\left(\int_{0}^{1} P_{N, t}(j)^{1-\lambda} d j\right)^{1 /(1-\lambda)}
$$

The optimal allocation of any given expenditure on non-traded goods yields the total demand for variety $j \in[0,1]$ :

$$
C_{N, t}(j)=\left(\frac{P_{N, t}(j)}{P_{N, t}}\right)^{-\lambda} C_{N, t}
$$

Households may borrow and lend in the form of non state-contingent bonds that are denominated in units of the traded goods. We assume that the borrowing rate $i_{t}^{F}$, charged on foreign debt depends on an exogenous world interest rate, $i^{*}$, and exogenous term $\xi_{t}$ that capture external shocks to the borrowing rate:

$$
\left(1+i_{t}^{F}\right)=\left(1+i^{*}\right)\left(1+\xi_{t}\right)
$$

Trade in foreign currency bonds is subject to portfolio adjustment costs. If households borrow an amount $D_{t+1}$, then the portfolio adjustment costs are $\frac{\kappa}{2}\left(D_{t+1}-\bar{D}\right)^{2}$, which are denominated in the units of the traded goods. Households can also obtain loans from domestic capital markets, with $B_{t}$ the stock of domestic currency debt.

Households own firms that produce two goods: traded and non-traded goods in the economy. Households accumulate capital and rent it out to the goods producing firms. Capital stocks in non-traded and traded sectors are assumed to evolve according to the following:

$$
K_{N, t+1}=I_{N, t}+(1-\delta) K_{N, t}
$$

\footnotetext{
${ }^{9}$ This price index is the minimum expenditure required to buy one unit of aggregate consumption non-traded good $C_{N, t}$. For the derivation see, for example, Corsetti and Pesenti (2005).
} 


$$
K_{T, t+1}=I_{T, t}+(1-\delta) K_{T, t}
$$

where investment in both sectors is traded good. Installation of capital in both sectors requires adjustment costs, which represent a basket of goods composed of non-traded goods and traded goods in the same mix as the household's consumption basket. We define capital adjustment costs as:

$$
\phi_{i, t}\left(\frac{I_{i, t}}{K_{i, t}}\right) K_{i, t}=\frac{\psi_{I}}{2}\left(\frac{I_{i, t}}{K_{i, t}}-\delta\right)^{2} K_{i, t}, \text { where } i=N, T,
$$

so $\phi^{\prime}>0$, and $\phi^{\prime \prime}>0$.

The household's budget constraint in nominal terms is:

$$
\begin{aligned}
P_{t} C_{t}+P_{t}\left(\phi_{N t} K_{N t}+\phi_{T t} K_{T t}\right)+P_{T t}\left(I_{N t}+I_{T t}\right) & =W_{t} H_{t}+S_{t} D_{t+1}-\left(1+i_{t}^{F}\right) S_{t} D_{t}+B_{t+1}-\left(1+i_{t}\right) B_{t}+ \\
& +R_{N t} K_{N t}+R_{T t} K_{T t}+P_{T t} O_{t}+ \\
& +\int_{0}^{1} \Pi_{N t}(j) d j-P_{T t} \frac{\kappa}{2}\left(D_{t+1}-\bar{D}\right)^{2}
\end{aligned}
$$

where $W_{t}$ is the wage rate; $R_{N t}$ and $R_{T t}$ are the nominal rates of return for households in the non-traded and traded sectors respectively; $D_{t}$ is the outstanding amount of foreign debt, denominated in foreign currency, $B_{t}$ is the stock of domestic debt, denominated in domestic currency, and $S_{t}$ is the nominal exchange rate expressed as units of domestic currency needed for one unit of foreign currency. The household owns $K_{N, t}$ and $K_{T, t}$ units of capital in the non-traded and traded sectors, makes additional investments in both sectors of $I_{N, t}$ and $I_{T, t}$, consumes $C_{t}$ and supplies $H_{t}$ units of labor, and receives profits from the firms producing the non-traded goods, $\int_{0}^{1} \Pi_{N t}(j) d j$. Households take as given the money coming from export of oil, those price is determined exogenously at the world markets. As a result, oil income is an exogenous, stochastic variable

$$
O_{t}=O \varepsilon_{t}
$$

where

$$
\log \left(\varepsilon_{t}\right)=\rho \log \left(\varepsilon_{t-1}\right)+\nu_{t}
$$


Since oil revenues are denominated in the units of the traded goods, and because $P_{T, t}=S_{t}$ following the assumption of a small open economy, $\varepsilon_{t}$ can be described as the world price of oil, denominated in foreign currency. It implies that $\nu_{t}$ shocks are international oil price shocks.

The household optimum is characterized by the following equations:

$$
\begin{gathered}
W_{t}=\eta H_{t}^{\psi} P_{t} C_{t}^{\sigma} \\
1=\beta E_{t}\left[\frac{C_{t}^{\sigma} P_{t}}{C_{t+1}^{\sigma} P_{t+1}}\left(1+i_{t+1}\right)\right] \\
q_{t}^{N}=\beta E_{t} \frac{C_{t}^{\sigma} P_{t}}{C_{t+1}^{\sigma} P_{t+1}}\left\{R_{N t+1}+P_{t+1}\left(\phi_{N, t+1}^{\prime} \frac{I_{N t+1}}{K_{N t+1}}-\phi_{N, t+1}\right)+q_{t+1}^{N}(1-\delta)\right\} \\
q_{t}^{N}=P_{T t}+P_{t}\left[\frac{C_{t}^{\sigma} P_{t}}{C_{t+1}^{\sigma} P_{t+1}} \frac{S_{t+1}}{S_{t}}\left(1+i_{t+1}^{F}\right)\right] \\
q_{t}^{T}=\beta E_{t} \frac{C_{t}^{\sigma} P_{t}}{C_{t+1}^{\sigma} P_{t+1}}\left\{R_{T, t+1}+P_{t+1}\left(\phi_{T, t+1}^{\circ} \frac{I_{T, t+1}}{K_{T, t+1}}-\phi_{T, t+1}\right)+q_{t+1}^{T}(1-\delta)\right\} \\
q_{t}^{T}=P_{T t}+P_{t} \phi_{T, t}^{\prime}
\end{gathered}
$$

along with the capital accumulation, (2.6)-(2.7), and budget constraint, (2.8), equations.

Equation (2.11) equates the marginal disutility of the labor effort to the utility value of the wage rate, and defines the households labor supply curve. Equation (2.12) is a Euler equation that determines intertemporal allocation: it equates the intertemporal marginal rate of substitution in consumption to the real rate of return on domestic bonds. Equation (2.14) is the counterpart of equation (2.13) for foreign bonds. Equation (2.14) is the pricing condition for physical capital in the non-traded sector. It equates the revenue from selling one unit of capital today $\left(q_{t}^{N}\right)$, to the discounted value of renting the unit of capital for one period, and then selling 
it, $R_{N, t+1}+q_{t+1}^{N}$, net of depreciation and adjustment $\operatorname{costs}^{10}$. Equation (2.15) relates the cost of producing a unit of capital in the non-traded sector to the shadow price of installed capital, or Tobin's Q, $q_{t}^{N}$. Equations (2.16), and (2.17) are the traded sector counterparts of (2.14) and (2.15). Equation (2.12) in conjunction with (2.13) yields the uncovered interest parity condition (UIP):

$$
E_{t}\left\{C_{t+1}^{-\sigma} \frac{P_{t}}{P_{t+1}}\left[\left(1+i_{t+1}\right)-\left(1+i_{t+1}^{F}\right) \frac{S_{t+1}}{S_{t}}\right]\right\}=0
$$

Given a decision on consumption $C_{t}$ the household allocates optimally the expenditure on $C_{N, t}$ and $C_{T, t}$ by minimizing the total expenditure $P_{t} C_{t}$ under the constraint (2.2), so demands for non-traded and traded goods are:

$$
\begin{gathered}
C_{N t}=a\left(\frac{P_{N, t}}{P_{t}}\right)^{-\rho} C_{t} \\
C_{T t}=(1-a)\left(\frac{P_{M, t}}{P_{t}}\right)^{-\rho} C_{t}
\end{gathered}
$$

\subsection{Production by Firms}

We assume a continuum of monopolistically competitive firms of measure unity in the non-traded sector, each producing output with the production function:

$$
Y_{N, t}(j)=A_{N} K_{N, t}(j)^{\alpha} H_{N, t}(j)^{1-\alpha}
$$

where $A_{N}$ is a productivity parameter, which is the same across the firms in the non-traded sector. Firms in the traded sector operate under perfect competition with the production function given by:

$$
Y_{T, t}(j)=A_{T} K_{T, t}(j)^{\gamma} H_{T, t}(j)^{1-\gamma}
$$

where $A_{T}$ is a productivity parameter, and is also the same across the firms in the traded sector. There are also a mass of one of firms producing traded goods. We assume all firms rent capital

\footnotetext{
${ }^{10}$ Adjustments are costs stemming from decreasing the capital stock. The installation function $\phi_{N t} K_{N t}$ as a function of $I_{N t}$ shifts upwards as $K_{N t}$ decreases, which is represented by $\partial / \partial K_{N t+1}\left(\phi_{N t+1} K_{N t+1}\right)=$ $-\phi_{N t+1}^{\prime} I_{N, t+1} / K_{N t+1}+\phi_{N t+1}$ in $(2.14)$.
} 
and labor in perfectly competitive factor markets. Cost minimization implies equations:

$$
\begin{gathered}
W_{t}=M C_{N, t}(1-\alpha) \frac{Y_{N, t}}{H_{N, t}} \\
R_{N, t}=M C_{N, t} \alpha \frac{Y_{N, t}}{K_{N, t}} \\
W_{t}=P_{T, t}(1-\gamma) \frac{Y_{T, t}}{H_{T, t}} \\
R_{T, t}=P_{T, t} \gamma \frac{Y_{T, t}}{K_{T, t}}
\end{gathered}
$$

where $Y_{N, t}=A_{N} K_{N, t}^{\alpha} H_{N, t}^{1-\alpha}$ and $Y_{T, t}=A_{T} K_{T, t}^{\gamma} H_{T, t}^{1-\gamma}$ are aggregate supply functions of non-traded and traded goods ${ }^{11}$. Demand for labor and capital in the non-traded goods sector is described by equations (2.23)-(2.24), where $M C_{N, t}$ represents the (nominal) marginal costs in that sector. It is noteworthy that the marginal costs in the non-traded sector are identical across firms as long as their production functions exhibit constant returns to scale and prices of inputs are fully flexible in perfectly competitive markets. Producers of the traded goods are price-takers, so that equations (2.25)-(2.26) describe the demand for labor and capital inputs in the traded sector, with $P_{T, t}$ representing the unit cost of production.

\subsection{Price setting in the non-traded sector}

In order to describe the price setting decisions we split firms into two groups according to their pricing behavior, following Steinsson (2003). In each period, each firm changes its price with probability $1-\theta_{N}$, and otherwise, with probability $\theta_{N}$, its price will rise at the steady state rate of inflation $\Pi_{N, t}=P_{N, t} / P_{N, t-1}$. Among those firms which reset their price, a proportion of $1-\omega$ are forward-looking and set prices optimally, while a fraction $\omega$ are backward-looking and set their prices according to a rule of thumb.

\footnotetext{
${ }^{11}$ With respect to aggregation in the non-traded sector, in the technical appendix I show that the non-traded market equilibrium equation has an additional term that deals with the distribution of prices in the non-traded sector. However, as shown in the appendix (see also Yun (1996), Erceg et. al. (2000) and Christiano et. al. (2001)), this term does not appear in the log-linear approximation of the resource constraint in the non-traded sector.
} 
Forward-looking firms are profit-maximizing and reset prices $\left(P_{N, t}^{F}\right)$ optimally, which in terms of log-deviations from the steady state implies:

$$
\widehat{p}_{N, t}^{F}=\widehat{m c}_{N, t}+E_{t} \sum_{i=1}^{\infty}\left(\theta_{N} \beta\right)^{i}\left[\widehat{m c}_{N, t+i}-\widehat{m c}_{N, t+i-1}\right]+E_{t} \sum_{i=1}^{\infty}\left(\theta_{N} \beta\right)^{i} \pi_{N, t+i}
$$

where $\pi_{N, t}$ is inflation in the non-traded sector and $\widehat{m c}_{N, t}$ stands for the deviation of real marginal costs from its steady state. As discussed in Christiano et al. (2001), relation (2.27) shows several important features of the behavior of the forward-looking firms. When firms expect real marginal costs to be higher in the future and/or expect future increases in the price level, then the firms set $\widehat{p}_{N, t}^{F}$ higher than $\widehat{m c}_{N, t}$. Christiano et al. (2001) describe this behavior as 'front loading'. Firms understand that they might not be allowed to change their price when higher real marginal costs or higher prices materialize. So, anticipating this, forward-looking firms set prices to maximize their current and future profits, taking into account the future evolution of real marginal costs and prices. Further, for derivation of the Phillips curve below, it is convenient to re-write relation $(2.27)$ as:

$$
\widehat{p}_{N, t}^{F}=\left(1-\beta \theta_{N}\right) \widehat{m c}_{N, t}+\beta \theta_{N} \widehat{p}_{N, t+1}^{F}+\beta \theta_{N} \pi_{N, t+1}
$$

Backward-looking firms set their prices according to the following rule:

$$
P_{N, t}^{B}=P_{N, t-1}^{r} \Pi_{N, t-1}\left(\frac{Y_{N, t-1}}{Y_{N, t-1}^{n}}\right)^{\vartheta}
$$

where $\Pi_{N, t-1}=P_{N, t-1} / P_{N, t-2}$ is the past period growth rate of prices in the non-traded sector, $Y_{N, t-1} / Y_{N, t-1}^{n}$ is output relative to the flexible-price equilibrium, $P_{N, t-1}^{r}$ is an index of prices set at date $t-1$, given in terms of log-deviations from the steady state (see Appendix) by:

$$
\widehat{p}_{N, t-1}^{r}=(1-\omega) \widehat{p}_{N, t-1}^{F}+\omega \widehat{p}_{N, t-1}^{N}
$$

The rule of thumb (2.29) shows that backward-looking firms set their prices equal to the average of the newly set prices in the previous period updated by the previous period inflation rate of the non-traded goods price level and by the deviation of the non-traded goods output relative to the flexible price equilibrium non-traded output. This assumption, as discussed in Galí and Gertler (1999) has the following appealing properties: first, the rule of thumb behavior converges to the optimal behavior over time; and second, $P_{N, t}^{B}$ depends only on information up 
to the period $t-1$, but implicitly incorporates past expectations about the future, since the price index $P_{N, t-1}^{r}$ is partly determined by forward-looking price setters.

For the whole non-traded sector, the price index in the non-traded sector is given by:

$$
P_{N, t}=\left[\left(1-\theta_{N}\right)(1-\omega)\left(P_{N, t}^{F}\right)^{1-\lambda}+\left(1-\theta_{N}\right) \omega\left(P_{N, t}^{B}\right)^{1-\lambda}+\theta_{N}\left(\Pi_{N} P_{N, t-1}\right)^{1-\lambda}\right]^{\frac{1}{1-\lambda}}
$$

Following Steinsson (2003), we can derive the following Phillips curve for the non-traded sector, written in terms of log-deviations from the steady state ${ }^{12}$ :

$$
\pi_{N, t}=\chi^{f} \beta E_{t} \pi_{N, t+1}+\chi^{b} \pi_{N, t-1}+\kappa_{1} \widehat{y}_{N, t-1}+\kappa_{2} \widehat{y}_{N, t}+\kappa_{m c} \widehat{m c}_{N, t}
$$

where the coefficients are:

$$
\begin{aligned}
\chi^{f} & =\frac{\theta_{N}}{\theta_{N}+\omega\left(1+\theta_{N} \beta-\theta_{N}\right)}, \quad \chi^{b}=\frac{\omega}{\theta_{N}+\omega\left(1+\theta_{N} \beta-\theta_{N}\right)}, \\
\kappa_{1} & =\frac{\omega \vartheta\left(1-\theta_{N}\right)}{\theta_{N}+\omega\left(1+\theta_{N} \beta-\theta_{N}\right)}, \quad \kappa_{2}=-\frac{\beta \theta_{N} \omega \vartheta\left(1-\theta_{N}\right)}{\theta_{N}+\omega\left(1+\theta_{N} \beta-\theta_{N}\right)}, \\
\kappa_{m c} & =\frac{\left(1-\beta \theta_{N}\right)(1-\omega)\left(1-\theta_{N}\right)}{\theta_{N}+\omega\left(1+\theta_{N} \beta-\theta_{N}\right)} .
\end{aligned}
$$

and where $\widehat{y}_{N, t}$ is the output gap in the non-traded sector, defined as the deviation from the flexible price output of the non-traded sector $\left(Y_{N, t}^{n}\right)$, and $m c_{N, t}$ are real marginal costs in the non-traded sector.

All coefficients are explicit functions of three model parameters: $\theta_{N}$ which measures the degree of price stickiness in the non-traded sector; $\omega$ which measures the degree of 'backwardness' in price setting, and the discount factor $\beta$. Coefficients on the output gaps, $\kappa_{1}$ and $\kappa_{2}$, also depend on the elasticity $\vartheta$. In this model, the degree of inflation inertia can be measured by the fraction of backward-looking firms, as a larger fraction of backward-looking firms implies a higher value of the coefficient of the lagged inflation, $\chi^{b}$. As one would anticipate, a rise in $\omega$ leads to a fall in the coefficients of current variables, $\kappa_{2}$ and $\kappa_{m c}$, and to a rise in the coefficient of the predetermined variable, $\kappa_{1}$. Moreover, a higher degree of backwardness in the model implies a lower weight on the currently expected future inflation, $\chi^{f}$. This is because only forward-looking firms react immediately to changes in current market conditions.

\footnotetext{
${ }^{12} \mathrm{~A}$ detailed derivation is given in the technical appendix.
} 
Note that when $\omega=0$ the Phillips curve collapses to the standard forward-looking specification:

$$
\pi_{N, t}=\frac{\left(1-\beta \theta_{N}\right)\left(1-\theta_{N}\right)}{\theta_{N}} \widehat{m c}_{N, t}+\beta E_{t} \pi_{N, t+1}=\lambda_{N} \widehat{m c}_{N, t}+\beta E_{t} \pi_{N, t+1}
$$

When $\omega=1$ the Phillips curve takes the specification:

$$
\pi_{N, t}=\frac{\theta_{N} \beta}{1+\theta_{N} \beta} E_{t} \pi_{N, t+1}+\frac{1}{1+\theta_{N} \beta} \pi_{N, t-1}-\frac{1-\theta_{N}}{1+\theta_{N} \beta}\left[\beta \theta_{N} \vartheta \widehat{y}_{N, t}-\vartheta \widehat{y}_{N, t-1}\right]
$$

As noted in Steinsson (2003), (2.34) has a unique bounded solution:

$$
\pi_{t}=\pi_{t-1}+\left(1-\theta_{N}\right) \vartheta \widehat{y}_{N, t-1}
$$

which is a form of the accelerationist Phillips curve and has no forward-looking component.

\subsection{Local Currency Pricing}

We assume that the price of the traded good is flexible and determined by the law of one price, So:

$$
P_{T, t}=S_{t} P_{T, t}^{*}
$$

where $P_{T, t}^{*}$ is the foreign currency price of the traded good, and $S_{t}$ is the nominal exchange rate. The economy is small also in the respect that the economy's export share is negligible in the foreign aggregate price index, implying that the foreign price of traded goods is equal to the

foreign aggregate price level, and we assume that it is equal to unity, so $P_{T, t}^{*}=P_{t}^{*}=1$, and $P_{T, t}=S_{t}$

Defining the real exchange rate as, $e_{t}=S_{t} P_{t}^{*} / P_{t}$, so the real exchange rate depreciates (appreciates) when $e_{t}$ rises (decreases). The rate of change of the real exchange rate is given as:

$$
\frac{e_{t}}{e_{t-1}}=\frac{1+\nu_{t}}{1+\pi_{t}}
$$

and the nominal exchange rate depreciation in period $t$ is given by:

$$
1+\nu_{t}=\frac{S_{t}}{S_{t-1}}
$$




\subsection{Monetary policy}

We assume that the monetary authority uses the nominal interest rate as the policy instrument. We consider two alternative monetary policy regimes: flexible and fixed exchange rate regimes. In the first, the flexible exchange rate regime monetary policy is characterized as a Taylor rule:

$$
\log \left(\frac{1+i_{t}}{1+i}\right)=\rho_{Y} \log \left(\frac{Y_{N t}}{Y_{N, t}^{n}}\right)+\rho_{\pi} \log \left(\frac{1+\pi_{N, t}}{1+\overline{\pi_{N}}}\right)
$$

where $\overline{\pi_{N}}$ is the target for the annual inflation in the non-traded sector, $i$ is the stationary value of the interest rate, and $Y_{N, t} / Y_{N, t}^{n}$ is output of the non-traded sector relative to its flexible-price equilibrium. Log-linearization of the feedback rule yields:

$$
\widehat{i}_{t}=\rho_{Y} \widehat{y}_{N, t}+\rho_{\pi} \pi_{t}
$$

where $\rho_{Y}>0$, and $\rho_{\pi}>1$ are the reaction coefficients on non-traded goods inflation and $\widehat{y}_{N, t}$ is the output gap in the non-traded sector.

Alternatively, monetary policy is characterized by the following interest rate rule that delivers a fixed exchange rate:

$$
1+i_{t}=\left(1+i_{t}^{F}\right)\left(\frac{S_{t}}{\bar{S}}\right)^{\omega_{S}}
$$

where $\omega_{S}>0$, and $S_{t}=\bar{S} \forall t$. Under this rule, the monetary authority pegs the nominal exchange rate at a target level $\bar{S}$ in all periods by varying the nominal interest rate in reaction to movements in the foreign interest rate and deviations of the nominal exchange rate from the target $^{13}$.

\subsection{Equilibrium}

The equilibrium of the economy is a sequence of prices $\left\{\mathrm{P}_{t}\right\}=\left\{W_{t}, i_{t}^{F}, i_{t}, P_{N, t}, S_{t}, R_{N, t}, R_{T, t}\right\}$ and quantities $\left\{\Theta_{t}\right\}=\left\{\left\{\Theta_{t}^{h}\right\},\left\{\Theta_{t}^{f}\right\}\right\}$ with

$$
\begin{aligned}
& \left\{\Theta_{t}^{h}\right\}=\left\{H_{t}, C_{t}, C_{N t}, C_{T t}, D_{t}, B_{t}, K_{N, t+1}, K_{T, t+1}, I_{N t}, I_{T t}\right\} \\
& \left\{\Theta_{t}^{f}\right\}=\left\{H_{N t}, H_{T t}, K_{N t}, K_{T t}, Y_{N t}, Y_{T t}, X_{T t}\right\}
\end{aligned}
$$

such that:

\footnotetext{
${ }^{13}$ Benigno et. al. (2005) show that such kind interest rate rule ensures determinacy of the exchange rate and the real economy. Such rules produce equality between the domestic and foreign interest rate endogenously in all periods as a feature of the rational expectations equilibrium.
} 
(1) given a sequence of prices $\left\{\mathrm{P}_{t}\right\}$ and a sequence of shocks, $\left\{\Theta_{t}^{h}\right\}$ is a solution to the representative household's problem;

(2) given a sequence of prices $\left\{\mathrm{P}_{t}\right\}$ and a sequence of shocks, $\left\{\Theta_{t}^{f}\right\}$ is a solution to the representative firms in non-traded and traded sectors;

(3) given a sequence of quantities $\left\{\Theta_{t}\right\}$ and a sequence of shocks, $\left\{\mathrm{P}_{t}\right\}$ clears the markets:

(i) Labor market:

$$
H_{X t}+H_{N t}=H_{t}
$$

(ii) Capital market:

$$
K_{N, t}^{S}=K_{N, t}^{D} \quad K_{X, t}^{S}=K_{X, t}^{D}
$$

(iii) Non-traded goods sector:

$$
\int_{0}^{1} Y_{N t}^{S}(j) d i=\Delta_{t} Y_{N t}^{D}
$$

where $\Delta_{t}$ is a measure of relative price dispersion in the non-traded goods sector ${ }^{14}$ and $Y_{N t}^{D}$ is the aggregate demand of non-traded goods in the economy, defined as:

$$
Y_{N t}^{D} \equiv a\left(\frac{P_{N t}}{P_{t}}\right)^{-\rho}\left[C_{t}+\phi_{N, t} K_{N t}+\phi_{T, t} K_{T t}\right]
$$

(iv) Traded goods sector:

$$
A_{T t}=Y_{T t}+I M_{T t}
$$

where domestic absorption of traded goods $A_{T t}$ is met via domestic production of traded goods $Y_{T t}$ and imports $I M_{T t}$ :

$$
A_{T t} \equiv(1-a)\left(\frac{P_{T t}}{P_{t}}\right)^{-\rho}\left[C_{t}+\phi_{N, t} K_{N t}+\phi_{T, t} K_{T t}\right]+I_{N t}+I_{T t}
$$

(v) Foreign loans market:

$$
D_{t}^{S}=D_{t}^{D}
$$

(vi) Domestic loans market:

$$
B_{t}=0
$$

\footnotetext{
${ }^{14}$ See technical appendix for more details on this.
} 
(vii) Balance of Payments:

$$
A_{T t}+\left(1+i_{t}^{F}\right) D_{t}+\frac{\kappa}{2}\left(D_{t+1}-\bar{D}\right)^{2}=D_{t+1}+Y_{T t}+O_{t}
$$

(4) Prices are set to satisfy (2.18), (2.38) (or(2.40)), (2.41), (2.42), (2.43), (2.47).

\section{Calibration}

In calibrating the model one period is meant to be one quarter. The parameter choices of the model are described in Table 1, while Table 3 reports macroeconomic ratios implied by the theoretical model. I set the following parameters of the utility function: $\sigma$, the inverse intertemporal elasticity of substitution in consumption, equal to unity ${ }^{15}$; the value of coefficient on labor $\eta=1$, and $\psi=0.45^{16}$, so that elasticity of the labor supply is 2.22 . The elasticity of substitution between non-traded and traded goods $(\rho)$ is set to $1.2{ }^{17}$

The value of $a$, the share of non-traded goods in CPI, is set to equal to 0.65 , which implies the steady state share of non-traded goods in GDP is 45 percent. The depreciation rate is set at 10 percent per annum, a standard value in the business cycle literature. The value of the adjustment cost parameter, $\psi_{I}$ is set at 0.1 . This is consistent with empirical estimates of the adjustment cost parameter in the literature, although these estimates are for developed countries $^{18}$.

The steady-state real interest rate faced by the small economy in international markets is set at 11 percent per annum, with a world interest rate $r^{*}$ of 4 percent and a country premium of 7 percent. These parameters yield a value of the subjective discount factor, $\beta$, of 0.973 . The steady state value of oil income, $O$, was chosen such that oil transfers constitute 25 percent of

\footnotetext{
${ }^{15}$ Ostry and Reinhart (1992) provides an estimate of $\sigma$ for a group of Asian countries at 0.8. Aurelio (2005) uses the value of $\sigma=1$ in her simulations. Gali and Monacelli (2002) assume log-utility of consumption, which also implies a unit intertemporal elasticity of substitution.

${ }^{16}$ Uribe and Yue (2005) also set $\psi=0.45$

${ }^{17}$ Ostry and Reinhart's estimates of the parameter for Asian and Latin American countries equal 0.655 and 0.76 respectively, using one set of instruments, and 1.15 and 1.1 for a different set of instruments respectively. Mendoza (2001) sets $\rho=1.46$.

${ }^{18}$ Hall (2002) estimates a quadratic adjustment cost for capital and finds a slightly higher value of 0.91 for $\psi_{I}$, on average, across industries. A much closer value of 0.096 is found recently by Groth (2005) for estimates of capital adjustment costs for UK manufacturing covering the period 1970-2000.
} 
GDP. I also set the steady state value of foreign borrowing equal to 60 percent of GDP. The elasticity of substitution between differentiated goods is set to equal 11, which implies a steady state mark-up of $10 \%$. This is within the range suggested by the literature. ${ }^{19}$

Table 1 Calibration of the model

\begin{tabular}{lll}
\hline \hline Parameter & Value & Description \\
\hline \hline$\sigma$ & 1 & Inverse of elasticity of substitution in consumption \\
$\beta$ & 0.973 & Discount factor \\
$\rho$ & 1.2 & Elasticity of substitution between non-traded and traded goods in $C_{t}$ \\
$\eta$ & 1 & Coefficient on labor in utility \\
$\psi$ & 0.45 & Inverse of elasticity of labor supply $(1 / \psi=2.22)$ \\
$\gamma$ & 0.65 & Share of capital in traded sector \\
$\alpha$ & 0.25 & Share of capital in non-traded sector \\
$\delta$ & 0.025 & Quarterly rate of capital depreciation (same across sectors) \\
$\psi_{Y}$ & 0.65 & Share on non-traded goods in CPI \\
$\psi_{I}$ & 0.1 & Investment adjustment cost (same across sectors) \\
$\kappa$ & 0.0001 & Portfolio adjustment costs \\
$\rho_{N}$ & 0.75 & Probability of fixed price \\
$\vartheta$ & 0.36 & $\begin{array}{l}\text { Elasticity of deviation of the output gap in the rule-of-thumb } \\
\text { Elasticity of substitution between differentiated goods }\end{array}$ \\
\hline \hline
\end{tabular}

In simulations, perhaps the most important variable is $\omega$, the proportion of rule-of-thumb price setters. As $0 \leqslant \omega \leqslant 1$, our model nests the purely forward-looking new Keynesian model ( $\omega=0)$, the purely backward-looking acceleration model $(\omega=1)$, as well as other models such as in Fuhrer and Moore (1995) $(0<\omega<1)$. Empirical studies conclude that an empirical Phillips curve has a statistically significant backward-looking component. The estimates of coefficients on 'backwardness' and 'forwardness', however, vary widely among studies. Backward-looking

\footnotetext{
${ }^{19}$ Gali (2003) sets $\lambda=11$ as well, while in Gali and Monacelli (2002) the value of this parameter is equal to 6. The empirically plausible range of $10 \%$ - 40\% for markups, as Gali et. al. (2001) discuss, yields similar results.
} 
behavior is of limited quantitative importance in the estimated specifications of Galí and Gertler (1999) and Benigno and Lopez-Salido (2006). Mehra (2004) finds an extremely backward-looking specification of the Phillips curve, while Fuhrer and Moore (1995) claim that an equal weight on forward and backward inflation terms matches the pattern of US data much better than either a purely backward-looking or purely forward-looking model.

Galí and Gertler (1999) estimate a Phillips curve by using non-linear instrumental variables (GMM), using a measure of marginal costs instead of a measure of the output gap, which is a close relative of the Phillips curve derived in this model. They report estimates of $\theta_{N}$ between 0.803 and $0.866, \beta$ between 0.885 and $0.957, \kappa_{m c}$ between 0.015 and $0.037,{ }^{20} \omega$ between 0.077 and 0.522 (with 3 out of their 6 estimates being between 0.2 and 0.3 ), $\chi^{f}$ between 0.62 and 0.92 (with 4 out of their 6 estimates being between 0.78 and 0.92 ), and $\chi^{b}$ between 0.085 and 0.383 . In this paper, I am interested in analyzing how backward-looking behavior affects adjustment dynamics in response to the shocks compared with forward-looking behavior. That is why I consider two limiting cases. In the first case, inflation exhibits very little persistence and price setters are almost completely forward-looking, assuming $\omega=0.01$. In the second case, inflation is almost completely persistent and I set $\omega=0.9$. These values of $\omega$, with the appropriate choice of elasticity $\vartheta$, imply the values of structural parameters of the Phillips curve, reported in Table 2.

To calibrate the parameter $\vartheta$, I follow Steinsson's procedure, which is as follows. The value of $\omega$ varies between zero and one. So, when $\omega \rightarrow 0$, it collapses to the familiar forward-looking specification $\pi_{N, t}=\lambda_{N} \widehat{m c}_{N, t}+\beta E_{t} \pi_{N, t+1}$, whilst when $\omega \rightarrow 1$, it collapses to $\pi_{t}=\pi_{t-1}+(1-$ $\left.\theta_{N}\right) \vartheta \widehat{y}_{N, t-1}$, which is an accelerationist Phillips curve. In calibrating $\vartheta$, Steinsson assumes that demand pressure is the same across these two extreme cases, i.e. $\lambda_{N}=\left(1-\theta_{N}\right) \vartheta$. Chosen in this way, $\vartheta=\left(1-\beta \theta_{N}\right) / \theta_{N}=0.36$.

Table 2 Values for the structural parameters of the Phillips curve for different values of $\omega$

\begin{tabular}{cccccc}
\hline$\omega$ & $\chi^{f}$ & $\chi^{b}$ & $\kappa_{1}$ & $\kappa_{2}$ & $\kappa_{m c}$ \\
\hline \hline 0.01 & 0.98 & 0.013 & 0 & 0 & 0.087 \\
0.9 & 0.46 & 0.55 & 0.05 & -0.036 & 0.004 \\
\hline \hline
\end{tabular}

\footnotetext{
${ }^{20}$ Note that their estimate of $\kappa_{m c}$ does not correspond exactly to $\kappa_{m c}$, coefficient before marginal costs in Phillips curve in our model, as our specification contains an additional term with the output gap.
} 
I follow the literature ${ }^{21}$ in setting $\theta_{N}=0.75$, which implies that, on average, prices last for one year.

In this paper I study a temporary improvement in the price of oil, which is represented by a shock to $\varepsilon_{t}$. The impact of productivity shocks is not examined and the values of the productivity parameters, $A_{N}$ and $A_{T}$, in two sectors are set to equal to unity.

With the benchmark parameters summarized in the Table 1 the model generates an economy that has the following structure in the steady state:

Table 3 Structure of the theoretical economy

\begin{tabular}{ll}
\hline \hline External debt/GDP & $60 \%$ \\
Traded production/GDP & $31 \%$ \\
Absorption of traded goods/GDP & $54 \%$ \\
Non-traded production/GDP & $44 \%$ \\
Oil/GDP & $25 \%$ \\
Investment in non-traded sector/GDP & $5 \%$ \\
Investment in traded sector/GDP & $9 \%$ \\
Capital in non-traded sector/GDP & 2.09 \\
Capital in traded sector/GDP & 3.83 \\
Consumption/GDP & $84 \%$ \\
Consumption of non-traded goods/GDP & $44 \%$ \\
Consumption of traded goods/GDP & $40 \%$ \\
Labor income/GDP & $41 \%$ \\
Employment in non-traded sector/Total Employment & $73 \%$ \\
Employment in traded sector/Total Employment & $27 \%$ \\
\hline \hline
\end{tabular}

\section{Simulations}

In this section I present results of simulations of the model under exogenous oil price shock. I study a temporary 1 percentage improvement in the price of oil. Before examining the results

\footnotetext{
${ }^{21}$ The micro analysis on price stickiness gives mixed results. Golosov and Lucas (2003) suggest that firms change prices on average about 2 quarters. Baudry's et al. (2004) analysis suggests 3 quarters, while Aucremanne and Dhyne (2004) find a value of 5.
} 
of simulations of the model to these shocks, I briefly discuss the flexible analogue of the openeconomy model and its responses to the same shocks. That provides a useful benchmark for the analysis of impulse responses of the model with sticky prices in the subsequent sections.

\subsection{Flexible price equilibrium}

The model collapses to the flexible price equilibrium in the case when firms change their price with probability one, that is $\theta_{N}=1$. We assume that in flexible price equilibrium there is no distinction between backward-looking and forward-looking firms, product markets are monopolistically competitive and firms set prices as a mark-up over marginal costs. Figures 1 illustrates impulse responses of the flexible price equilibrium model to the oil shock.

\subsection{Sticky price equilibrium}

In this section I report results from simulations of the sticky-price model to oil shock under forward-looking and backward-looking Phillips curves (under two different exchange rate regimes).

\subsubsection{Flexible exchange rate regime}

Figure 2 displays impulse responses to the shock for the value $\omega=0.01$, while figure 3 shows the reaction of the variables to the shock in the case of $\omega=0.9$.

A positive oil shock increases demand for both non-traded and traded goods. As in the nontraded sector prices are sticky and output is demand-determined, the firms that are not able to reset prices increase output as long as their prices are above marginal costs. This pushes demand for labor up. As no imperfections exist in the labor market, the nominal wage must increase. Due to the price stickiness, this generates an increase in the real wage. As real marginal costs increase on the impact of the shock, firms - those able to reset their prices - find it profitable to set a price above the average price of the previous period. In setting their price, forward-looking firms, due to the 'front loading' behavior, also take into account the future expected changes in real marginal costs. So, the price set by those firms is above the average price that prevailed in the previous period, which causes an increase in the price of non-traded goods and inflation in that sector. 
This is very different from what happens if inflation is almost entirely backward-looking. In that case inflation rises only slightly on the impact of the shock, because backward-looking firms do not react contemporaneously to unexpected shocks. But as real marginal costs rises in the non-traded sector and some (even very small) fraction of forward-looking firms set prices higher than in previous periods, inflation starts picking up in the non-traded sector in subsequent periods.

Under both cases the central bank responses to the shock by increasing the (nominal) interest rate. The real interest rate also rises, given the Taylor principle. This monetary tightening helps to suppress demand, directly via the real interest rate effect and indirectly via its effect on the real exchange rate. Both of these effects curb inflation. There is a corresponding increase in the output gap, which causes additional monetary tightening and reinforces the interest rate effect.

The nominal exchange rate appreciates on the impact of the positive demand shock. Thereafter, the higher interest rate results in a nominal depreciation of the exchange rate via the uncovered interest parity condition (UIP). The long-run depreciation of the nominal exchange rate is offset by an increase in the CPI price index of the same magnitude, so that in the long-run the real exchange rate moves back to its initial level. Thus, with an independent monetary policy the nominal exchange rate facilitates adjustment to the shock, which is reflected in a smooth movement of the real exchange rate back to equilibrium level.

Two further points about the behavior of the real interest rate and inflation are worth noting. First, in case of $\omega=0.9$, the response of inflation is hump-shaped: inflation slowly increases and then converges to its steady state at a very slow speed as well. It seems to peak about five quarters after the shock. Second, despite very different dynamic responses of inflation and the (nominal) interest rate in the two cases, the real interest rate responses are very similar. This is because nominal interest rates closely follows the dynamics of inflation, and hence the real interest rate reaction in case of the accelerationist Phillips curve has the same pattern of behavior as in the case of the forward-looking Phillips curve. So, both real interest rates rise on the impact of the shock and then gradually converge to zero in the long-run. Given similar variations in the real interest rate, it is not surprising that the reaction of real variables are very similar too. Moreover, those responses are much like that in the flexible price model.

As discussed in Woodford (2003), such a Taylor rule policy, with characteristics above, would 
succeed in stabilizing inflation. As a result, the flexible price equilibrium is replicated here in the sense that real variables respond to the oil shock in a similar way to reactions of variables in the flexible-price model. In general, as noted by Woodford (2003), required variations in the natural rate of interest in response to the various types of shocks to replicate an equilibrium consistent with stable prices cannot be achieved through a simple Taylor rule. The assumption in our model, which is crucial in replicating the flexible price outcome, is flexibility of prices of traded goods. As shown in Smets and Wouters (2002), when prices of both sectors are sticky, there will be a trade-off between stabilizing prices of domestic goods and stabilizing imported price inflation. If one of these two sectors is flexible, it is optimal for the central bank to stabilize inflation in the sector with sticky prices, and the flexible price equilibrium is replicated. This result is consistent with earlier work by Aoki (2001), who also finds within two-sector model (a flexible price and sticky price sector, but without inflation inertia) that it is optimal to target inflation in the sticky-price sector, rather than to target aggregate inflation. When inflation is completely stabilized, the responses of the economy are equivalent to those of the flexible price model.

\subsubsection{Fixed exchange rate regime}

In this section I report results from similar simulations with a fixed exchange rate. The capitalmobility condition is then simply $i_{t}=i_{t}^{F}$. Now a country must give up an independent monetary policy to keep the exchange rate fixed. The relevant impulse responses are summarized in Figures 4 and 5 below.

Forward-looking Phillips curve $(\omega=0.01)$

There are two features of impulse response functions (IRFs) in the fixed exchange rate regime, compared to flexible exchange rate regime, which are worth noting. First, short-run reactions of real variables and inflation are stronger in the fixed exchange-rate regime. Second, responses of real variables (except capital and investment in the non-traded sector) are hump-shaped. The reason for such different propagation of the oil shock in the fixed exchange rate case can be seen as follows.

Given that the domestic interest rate is tied to the foreign rate and the fact that inflation rises on the impact of the shock, there is no short-run increase in the real interest rate in the 
country, as there was when the exchange rate could adjust. In fact, the real interest rate declines, which provides additional stimulus to the economy and as a result the reaction of the variables are stronger compared with what observed under floating exchange rate regime.

In order to explain hump-shaped response to the shock, let's focus on three key elements of the adjustment process: (i) the real interest rate; (ii) the real exchange rate; and (iii) the nominal exchange rate. As discussed earlier, the real interest rate falls on the impact of the shock, which puts upward pressure on output in the non-traded sector. However, forward-looking behavior implies that the real interest rate is expected to be higher in subsequent periods, as they know the long-run value of the price level and expect prices to fall. So, inflation jumps up on the impact of the shock and then gradually falls as more and more price-setters adjust their prices to the new optimal level. The real interest rate is negative on the impact of the shock, but then starts rising, having a stabilizing effect. Moreover, there is another stabilizing channel, coming from the real exchange rate.

As inflation remains positive throughout the adjustment period towards the long-run equilibrium level, the country's price level rises for some time and its real exchange rate declines (appreciates) for some time. This causes deterioration in net exports that results in a fall in demand for non-traded output. When demand falls low enough (precisely at the moment when the real interest rate returns to zero), prices start falling, and real exchange rate start depreciating. From here onwards, the dynamics of real variables are shaped by real exchange rate behavior only. Depreciation of real exchange rate will cause an improvement in net exports and that will cause an increase in the demand for non-traded output. Output increases gradually towards its long-run value. This explains the hump-shaped reaction of output in response to the shock. Similarly, hump-shaped responses of all other real variables are consequences of the same type of hump-shaped response of the real exchange rate.

Such behavior of the real exchange rate is a result of the third channel of the adjustment process, or actually its absence: the nominal exchange rate. As discussed above, with an independent monetary policy with sticky prices, the nominal exchange rate carries out the burden of adjustment, resulting in a smooth response of the real exchange rate. In contrast, with a fixed exchange rate, prices do all the adjustment, which causes equivalent changes in the real exchange rate. But because prices are sticky, an equivalent change in the real exchange rate would not be 
quick and immediate. This results in the hump-shaped behavior of the real exchange rate.

Backward-looking Phillips curve $(\omega=0.9)$.

The main feature of adjustment when there is a high proportion of backward-looking firms is that it is slow and cyclical. The oscillations of the series of the non-traded sector are due to the evolution of backward-looking prices during the adjustment period towards steady state and the fixed exchange rate regime assumption. As discussed above, backward-looking behavior does not modify significantly the responses of the economy to the shocks in the case of a flexible exchange rate regime. However with commitment to the fixed exchange rate, the country gives up independent monetary policy and backward-looking behavior changes the adjustment dynamics of the economy to the shock considerably.

To understand oscillatory responses to the shock, as before, let's focus on three key elements of the adjustment mechanism: the real interest rate, the real exchange rate, and the nominal exchange rate. As the output gap is positive on the impact of the shock, inflation starts rising gradually (because of inertia) and the real interest rate starts falling for some time. This falling real interest rate would cause further output gains which could push prices further up and in turn cause the real interest rate to fall further, and so on. This could be destabilizing. This destabilizing real interest rate mechanism has become known as 'Walters critique', because of the name of Sir A. Walters, who drew attention to the potentially destabilizing real interest rate response at the time when the UK entered the ERM in $1990 .^{22}$

However, the real exchange rate channel outweighs the destabilizing effect coming from real interest rate movements. Temporary real appreciation, initially very sluggish, is great enough to stabilize the economy. Comparison of the paths of the real exchange rate in the face of oil shock in figures 3 and 5 confirms that the real exchange rate appreciates more in the case of a fixed exchange rate regime than in a flexible exchange rate case. So, real exchange rate appreciation reduces demand, by having a stronger effect than the real interest rate and demand starts falling after initial increase.

In addition, the presence of forward-looking firms (though a small proportion) can reinforce

\footnotetext{
${ }^{22}$ The destabilizing real interest rate effect first has been notied by Wicksell (1907). Walter's mechanism is similar and it happens when an inflationary economy entering a fixed exchange rate regime is forced to reduce nominal interest rates, which in turn will reduce real interest rates, stimulate the economy and exacerbate inflation.
} 
the stabilizing real exchange rate effect on the economy. This is because forward-looking consumers know that, as prices of non-traded goods are anchored by the price level outside the country, and if prices rise they would need to fall again, which would in due course cause the real interest rate to increase again. That would lead them to reduce their expenditure and thus demand. Thus, forward-lookingness in price setting helps to prevent instability coming from the real interest rate channel. The higher proportion of forward-looking firms, the lower consequences of the destructive Walters effects and a more smooth adjustment path. That is why, in most earlier papers on monetary policy in small open economies the 'Walters critique' problems are absent, because these papers assume forward-looking wage and price setters.

A gradual rise in inflation causes an increase in the price of non-traded goods, which will reach a level high enough to reduce demand and cause the output gap return to zero. However, at this point prices are still rising because of the rule-of-thumb behavior of backward-looking firms. This will lead to a further decline in the demand for non-traded goods, which will cause a further fall in the output gap. The output gap falls substantially causing a fall in the price of non-traded goods, and thus leading to a decline in inflation so that inflation reaches its longrun equilibrium level. However, at this point the output gap is below its potential level, so with an accelerationist Phillips curve ${ }^{23}$ it is necessary for the inflation rate to fall further, and inflation will start falling below the steady state level. This explains the oscillatory response of the economy to an oil shock in the case of a fixed exchange rate regime. As in the case of the forward-looking Phillips curve discussed earlier, in the absence of a 'shock absorbing' role of the nominal exchange rate, the real exchange rate facilitates adjustment to the shock, resulting in an oscillatory reaction. ${ }^{24}$

\footnotetext{
${ }^{23}$ Under accelerationist Phillips curve, $\pi_{t}=\pi_{t-1}+\varsigma g a p_{t}$ inflation tends to rise when output is above potential and fall when it is below.

${ }^{24}$ It is necessary to note that the problem of adjusting to the external shocks in a small open economy with fixed exchange rate is similar, in many respects, to the problems faced by an economy in a monetary union. The approach in this paper is closest in spirit to that of Westaway (2003), who examines the key adjustment mechanisms available for a country in face of shocks inside and outside of the monetary union.
} 


\section{Conclusion}

This paper studies implications of inflation persistence on the dynamic adjustment to the external shocks in a small open economy with endogenous inflation persistence. It is shown that the country's adjustment paths are slow and cyclical if there is a significant backward-looking element in the inflation dynamics with a fixed exchange rate. Such adjustment dynamics are moderated if there is a higher proportion of forward-looking price setters. In the case of an almost entirely forward-looking Phillips curve, the responses of variables become hump-shaped. The reason is that with a fixed exchange rate, prices do all the adjustment, which causes equivalent changes in the real exchange rate. But because prices are sticky, an equivalent change in the real exchange rate would not be quick and immediate. This results in the hump-shaped behavior of the real exchange rate as well as other real variables of the model. In contrast, with an independent monetary policy, a freely floating exchange rate carries out the burden of adjustment, which results in a smooth response of the real exchange rate.

Obviously, the objective of this paper has been to provide detailed analysis of the effects of inflation inertia on dynamic adjustment to the shocks under alternative exchange rate regimes, fixed and flexible. Although the results suggest that fixed exchange rates can be potentially disadvantageous in face of the real shocks in a small open economy, the merits of alternative exchange rate regimes should be evaluated by using utility-derived welfare function. Such welfare-based analysis will allow study the benefits of different exchange rate regimes under different assumptions about price-setting behaviour. This could be an interesting extension of the paper which I leave for future research.

\section{References}

[1] Allsopp, C., Vines, D., 2006. Fiscal policy, labor markets, and the difficulties of intercountry adjustment within EMU, forthcoming in Cobham, D. (Ed.), The Travails of the Eurozone, Palgrave Macmillan, London.

[2] Angeloni, I., Aucremanne, L., Ehrmann, M., Galí, J., Levin, A., Smets, F., 2005. New evidence in inflation persistence and price stickiness in the Euro area: implications for 
macro modelling, manuscript, ECB.

[3] Angeloni, I., Aucremanne, L., Ehrmann, M., Galí, J., Levin, A., Smets, F., 2004. Inflation persistence in the euro area: preliminary summary of findings, manuscript, ECB.

[4] Aoki, K., 2001. Optimal monetary policy responses to relative-price changes. Journal of Monetary Economics 48, 55-80.

[5] Arellano, C., Mendoza, E., 2002. Credit frictions and 'Sudden Stops' in small open economics: an equilibrium business cycle framework for emerging market crises. NBER Working Paper, No. 8880, Cambridge, MA.

[6] Aucremanne, L., Dhyne, E., 2004. How frequently do prices change? evidence based on the micro data underlying the Belgian CPI. ECB, Working Paper, No. 331.

[7] Aurelio, M., 2005. The performance of monetary and fiscal rules in an open economy with imperfect capital mobility. Research Working Paper, 05-01, The Federal Reserve Bank of Kansas City, Economic Research Department.

[8] Ball, L.,1994. Credible disinflation with staggered price setting. American Economic Review 84 (March), 282-289.

[9] Baudry, L., Le Bihan, H., Sevestre, P., Tarrieu, S., 2004. Price rigidity. evidence from the French CPI micro-Data. ECB Working paper, No. 331.

[10] Benigno, G., Benigno, P., Ghironi, F., 2003. Interest rate rules for fixed exchange rate regimes. mimeo, Boston College.

[11] Benigno, G., Thoenissen, C., 2003. Equilibrium exchange rates and supply-side performance. The Economic Journal 113, 103-124.

[12] Benigno, P., Lopez-Salido, J. D., 2002. Inflation persistence and optimal monetary policy in the Euro area. International Finance Discussion papers, No. 749.

[13] Bils, M., Klenow, P., 2004. Some evidence on the importance of sticky prices. Journal of Political Economy 112(5), 947-985. 
[14] Calvo, G., 1983. Staggered prices in a utility maximizing framework. Journal of Monetary Economics 12, 383-398.

[15] Chari, V., Kehoe, P., McGrattan, E., 2000. Sticky price models of the business cycle: can the contract multiplier solve the persistence problem? Econometrica 68(5), 1151-1179.

[16] Christiano, L., Eichenbaum, M., Evans, C., 2001. Nominal rigidities and the dynamic effects of a shock to monetary policy. NBER Working Paper No. 8403.

[17] Clarida, R., Galí, J., Gertler, M., 1999. The science of monetary policy: a new Keynesian perspective. Journal of Economic Literature 37, 1661-1707

[18] Corsetti, G., Pesenti, P., 2005. The simple geometry of transmission and stabilization in closed and open economies. NBER Working paper, No. 11341.

[19] Devereux, M., Lane, P., Xu, J., 2004. Exchange rates and monetary policy in emerging market economies. IIIS Discussion Paper, no. 36, August 2004.

[20] Erceg, C., Henderson, J., Dale, W., Levin, A., 2000. Optimal monetary policy with staggered wage and price contracts. Journal of Monetary Economics 46 (2), 281-313.

[21] Erceg, C., Levin, A., 2003. Imperfect credibility and inflation persistence. Journal of Monetary Economics 50, 915-944.

[22] Fisher, S., 1977. Long-term contracts, rational expectations, and the optimal money supply rule. Journal of Political Economy 85, 191-205.

[23] Fuhrer, J., Moore, G., 1995. Inflation persistence. Quarterly Journal of Economics 440 (February), 127-159.

[24] Galí, J., 2003. New perspectives on monetary policy, inflation, and the business cycle, in Dewatripont, M., Hansen, L., Turnovsky, S. (Eds.), Advances in Economic Theory, vol. III, Cambridge University Press, pp. 151-197.

[25] Galí, J., Gertler, M., 1999. Inflation dynamics: a structural econometric Analysis. Journal of Monetary Economics 44, 95-222 
[26] Galí, J., Gertler, M., Lopez-Salido, J. D., 2001. European inflation dynamics. European Economic Review 45, 1237-1270.

[27] Galí, J., Monacelli, T., 2002. Monetary policy and exchange rate volatility in a small open economy. NBER Working Paper, No. 8905.

[28] Golosov, M., Lucas, R., 2003. Menu costs and Phillips curves. NBER Working Paper, No. 10187.

[29] Gordon, R., 1990. What is New-Keynesian economics? Journal of Economic Literature, 28(3), 1115-1171.

[30] Groth, C., 2005. Estimating UK capital adjustment costs. Working Paper no. 258, Bank of England, London, UK.

[31] Hall, R., 2002. Industry dynamics with adjustment costs. NBER Working Paper no.8849, March 2002.

[32] Kuralbayeva, K., Vines, D., 2006. Terms of trade shocks in an intertemporal model: should we worry about the Dutch disease or excessive borrowing? Discussion Paper No. 5857, Centre for Economic Policy Research, London.

[33] Lane, P., 2001. The New Open Economy Macroeconomics: a survey. Journal of International Economics 54, 235-266.

[34] Leitemo, K., 2002. Inflation persistence: should it influence your choice of monetary policy strategy? in Sepp U., Randveer, M., (Eds.), Alternative Monetary Regimes in Entry to EMU, Bank of Estonia, Tallin, pp. 67-91.

[35] Levin, A., Moessner, R., 2005. Inflation persistence and monetary policy design: An Overview. ECB Working Paper, No. 539.

[36] Mankiw, G., 1985. Small menu costs and large business cycles: a macroeconomic model of monopoly. Quarterly Journal of Economics 100 (Supplement), 529-539.

[37] Mankiw, G., 2001. The inexorable and mysterious tradeoff between inflation and unemployment. The Economic Journal 111, C45-C61. 
[38] Mankiw, G., Reis, R., 2001. Sticky information versus sticky prices: a proposal to replicate the New Keynesian Phillips curve. Quarterly Journal of Economics 117, 1295-1328.

[39] Mehra, Y., 2004. The output gap, expected inflation and inflation dynamics: another look. Topics in Macroeconomics 4(1), 1-19.

[40] Mendoza, E., 2001. Credit, prices, and crashes: business cycles with a sudden stop. NBER Working Paper, No. 8338, Cambridge, MA.

[41] Nakamura, E., Steinsson, J., 2006. Five facts about prices: a reevaluation of menu cost models. mimeo, Harvard University.

[42] Obstfeld, M., Rogoff, K., 2002. Foundations of international macroeconomics, MIT Press.

[43] Ostry, J., Reinhart, C., 1992. Private saving and terms of trade shocks: evidence from developing countries. IMF Staff Papers, International Monetary Fund, 39, 495-517.

[44] Roberts, J., 1997. Is inflation sticky? Journal of Monetary Economics 39, 173-196.

[45] Rudebusch, G., Svensson, L., 1999. Policy rules for inflation targeting, in Taylor, J., (ed), Monetary Policy Rules, The University of Chicago Press, Chicago, pp. 203-246.

[46] Schmitt-Grohè, S., Uribe, M., 2002. Closing small open economy models. Journal of International Economics 1, 1-23.

[47] Smets, F., Wouters, R., 2002. Openness, imperfect exchange rate pass-through and monetary policy. Journal of Monetary Economics 49, 947-981.

[48] Steinsson, J., 2003. Optimal monetary policy in an economy with inflation persistence. Journal of Monetary Economics 50, 1425-1456.

[49] Svensson, L., 1997. Inflation forecast targeting: implementing and monitoring inflation targets. European Economic Review 41, 1111-1146.

[50] Taylor, J., 1980. Aggregate demand and staggered contracts. Journal of Political Economy $88,1-22$. 
[51] Uribe, M., Yue, V., 2005. Country spreads and emerging countries: Who Drives Whom?", mimeo, April 2005.

[52] Walters, A., 1998. Walters critique, in the Economics and Politics of Money: The Selected Essays of Alan Walters, Cheltenham: Edward Elgar.

[53] Westaway, P., 2003. Modeling shocks and adjustment mechanisms in EMU. HM Treasury, UK, London.

[54] Wicksell, K., 1907. The influence of the rate of interest on prices. Economic Journal 17(66), 213-220.

[55] Woodford, M., 2003, Interest and prices, Princeton: Princeton University Press.

[56] Yun, T., 1996. Nominal price rigidity, money supply endogeneity, and business cycle. Journal of Monetary Economics 37(2), 345-370.

\section{Appendix}

This section presents the dynamic responses of the model to different shocks. We examine responses of the following main variables of the model:

\begin{tabular}{ll|ll}
\hline \hline$K_{N}$ & capital stock in the non-traded sector & $K_{T}$ & capital stock in the traded sector \\
$I_{N}$ & investment in the non-traded sector & $I_{T}$ & investment in the traded goods \\
$Y_{N}$ & production of the non-traded sector & $Y_{T}$ & domestic production of the traded goods \\
$H_{N}$ & employment in the non-traded goods & $H_{T}$ & employment in the traded sector \\
$C$ & consumption & $H$ & total employment \\
$C_{N}$ & consumption of non-traded goods & $C_{T}$ & consumption of the traded goods \\
$D$ & foreign debt & $A_{T}$ & domestic absorption of traded goods \\
$P_{N}$ & CPI adjusted price of the non-traded goods & $w$ & CPI adjusted wage rate \\
$T B / Y$ & trade balance-to-GDP ratio & $C A / Y$ & current account-to-GDP ratio \\
$Y_{n} g a p$ & output gap & $\pi_{n}$ & inflation in the non-traded sector \\
$R E R$ & real exchange rate & & \\
\hline \hline
\end{tabular}



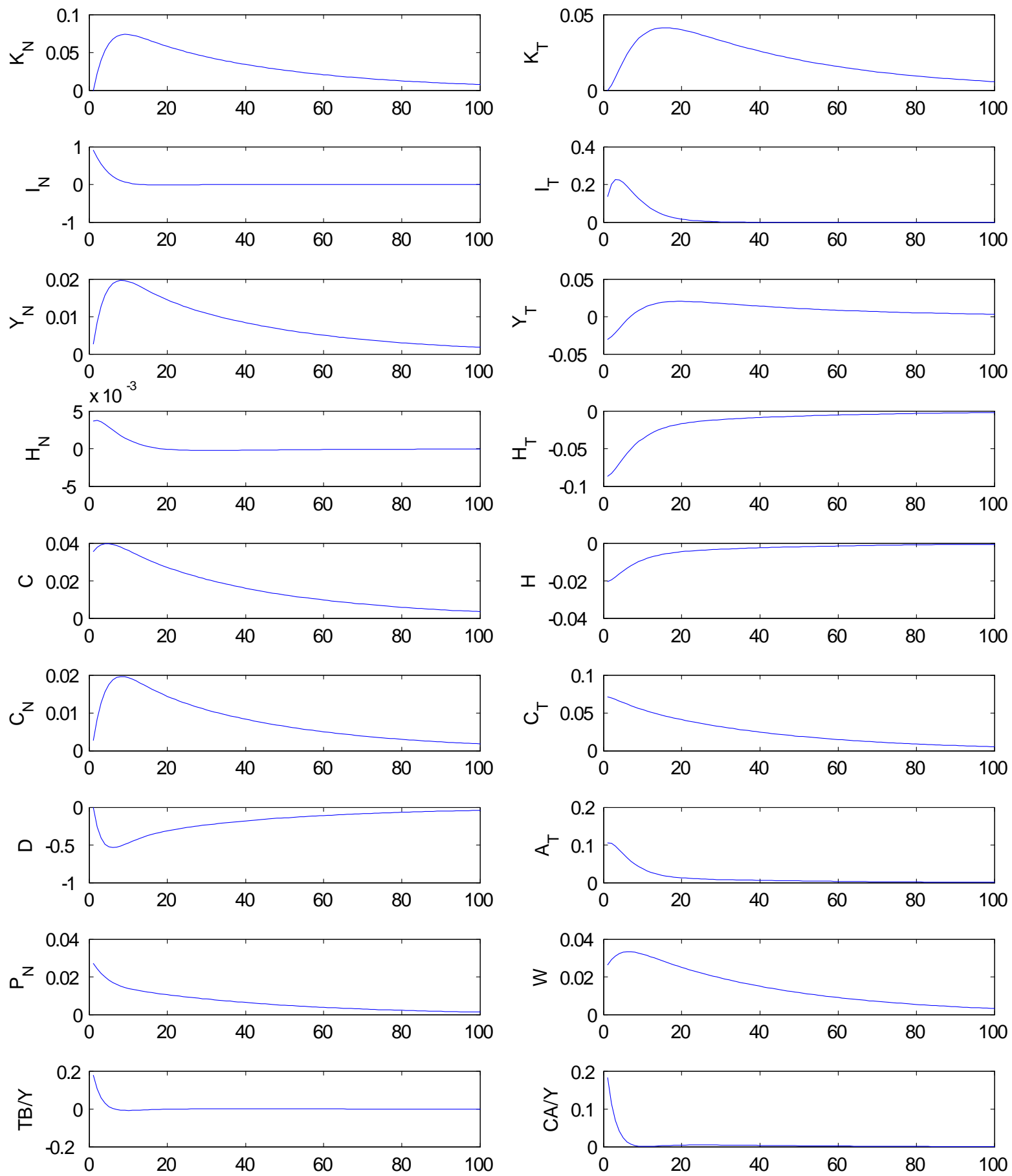

Figure 1: Flexible price model 

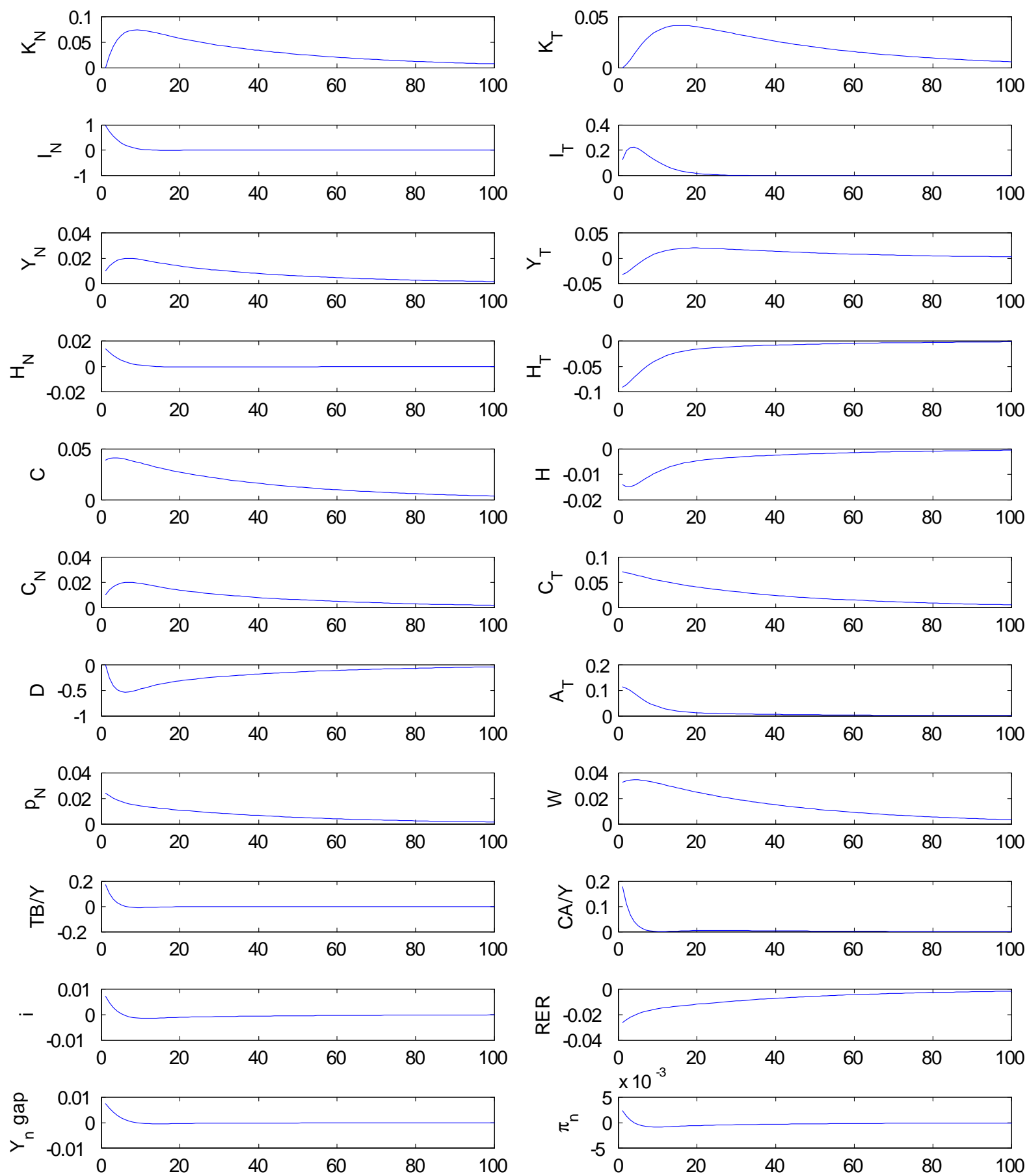

Figure 2: Sticky price model: flexible exchange rate regime, $\omega=0.01$ 

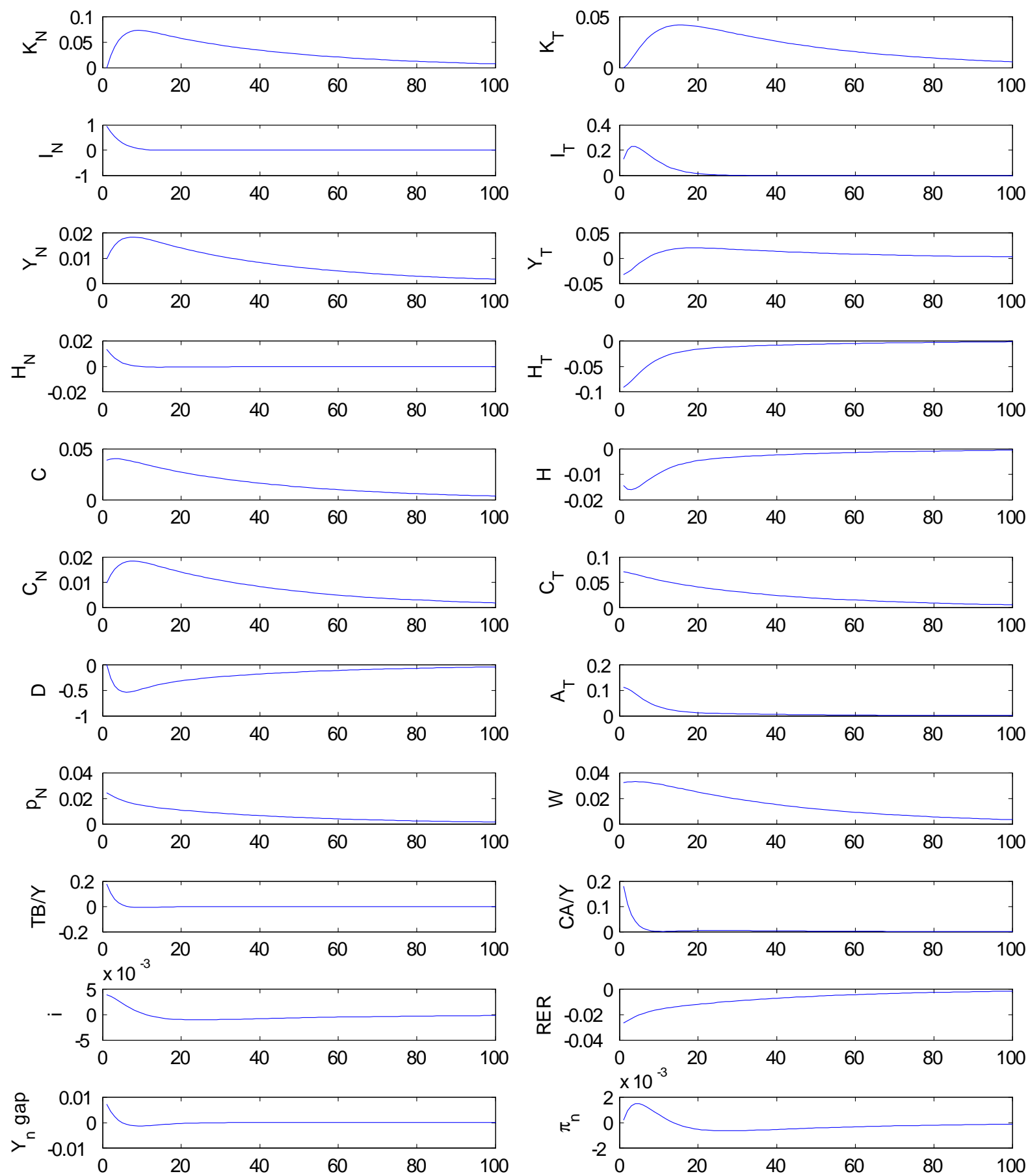

Figure 3: Sticky price model: flexible exchange rate regime, $\omega=0.9$ 

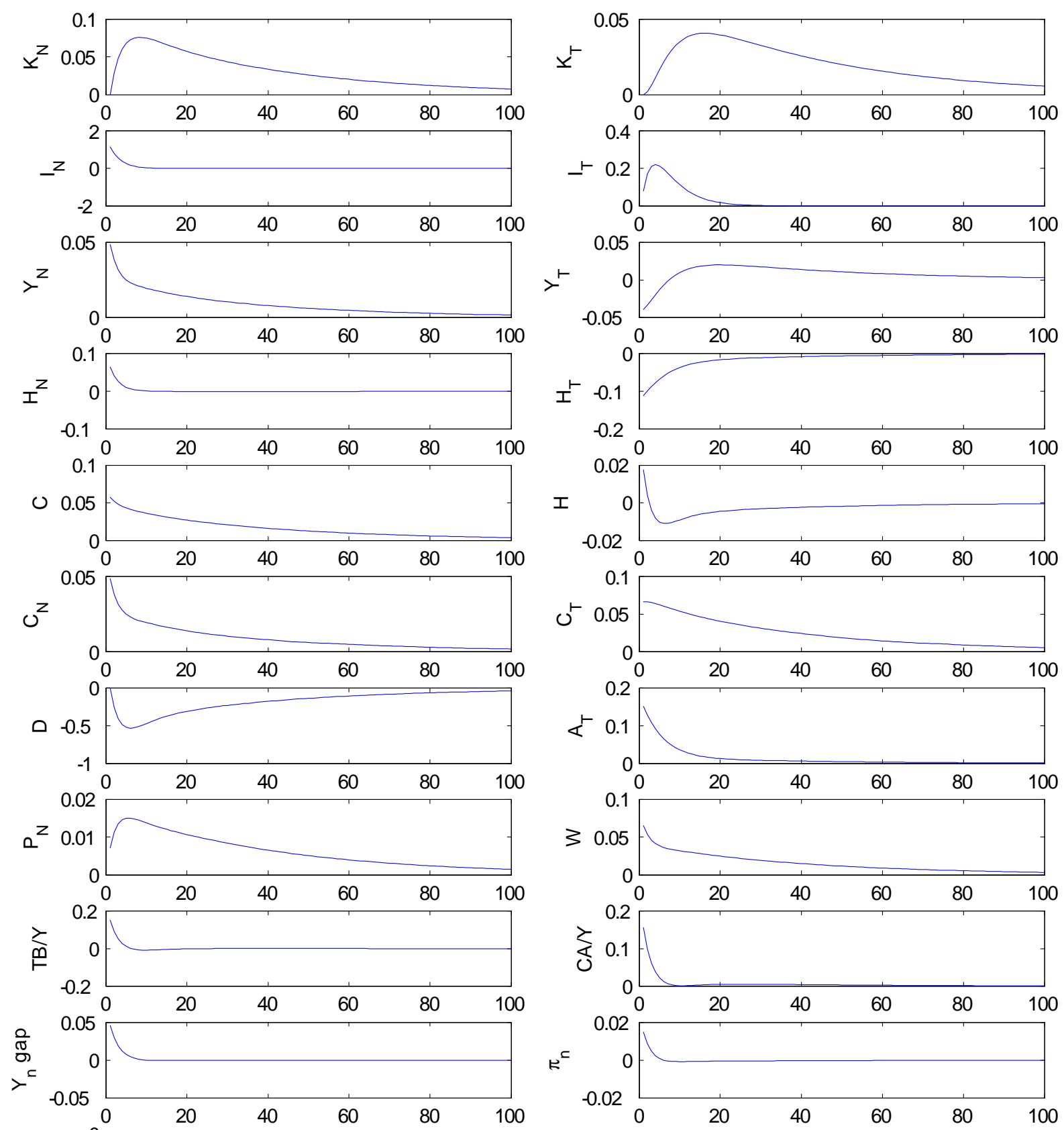

Figure 4: Sticky price model: fixed exchange rate refime, $\omega=0.01$ 

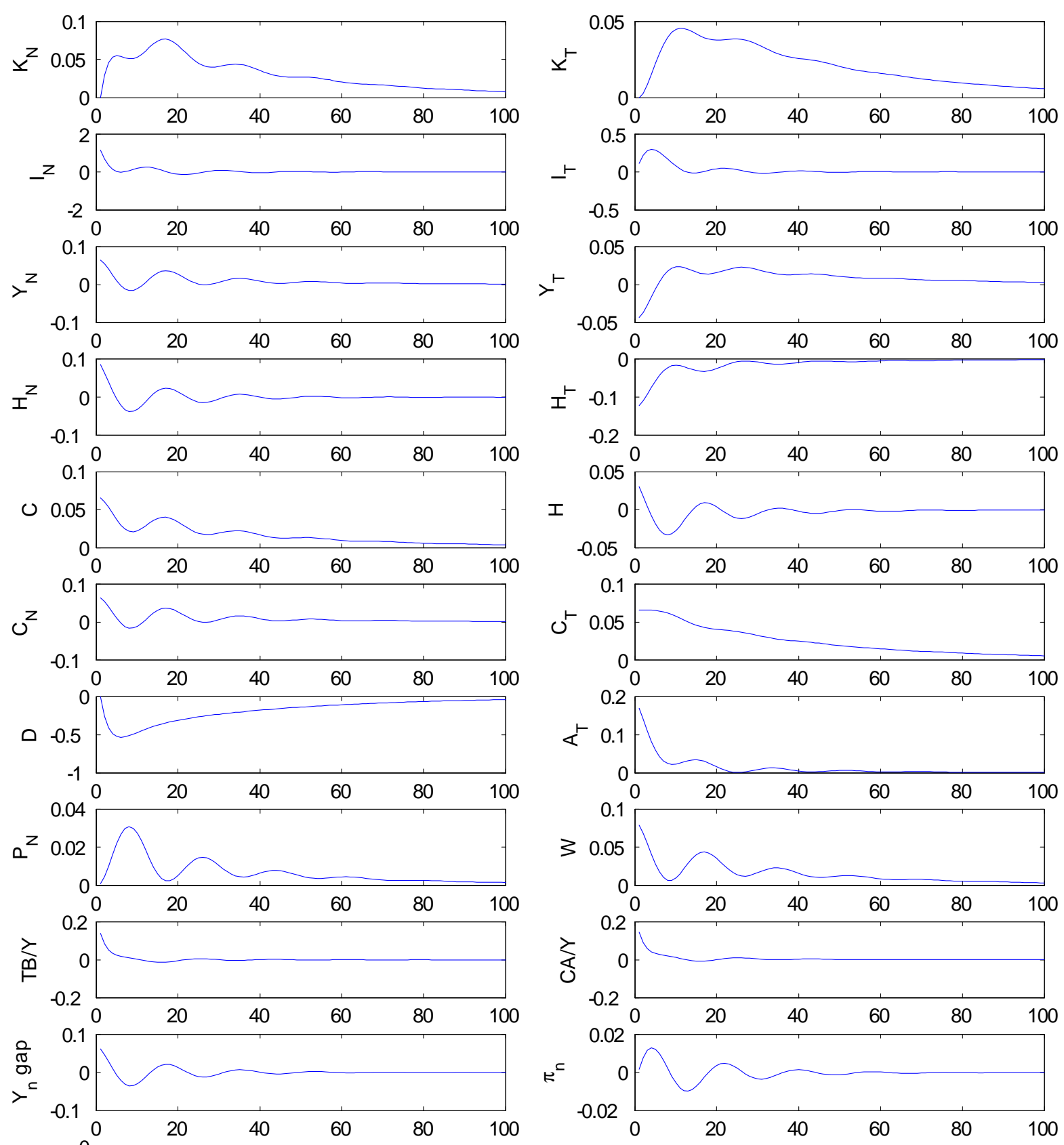

Figure 5: Sticky price model: fixed exchange rate regime, $\omega=0.9$ 


\section{Technical appendix (not to be published)}

\subsection{Production}

In this subsection we focus on the structural equations arising from the representative firm's decision problem that concern production, labor and capital demand. In the next subsection we focus on pricing implications. So, we think about breaking the firm into two separate parts for planning purposes: production unit and pricing unit. First, the production unit takes, given the output level of the firm and the rental price of capital and wage rate (each firm operates under perfect competition in the inputs markets). Thus, each firm $j$ in the non-traded sector determines its labor and capital demand so as to minimize its total costs. Second, the pricing unit determines the price of the firm's output, taking into account costs of production and demand conditions for the output.

$$
\min _{K_{N, t}(j), H_{N, t}(j)} W_{t} H_{N, t}(j)+R_{N, t} K_{N, t}(j)
$$

subject to $Y_{N, t}(j)=A_{N} K_{N, t}^{\alpha}(j) L_{N, t}^{1-\alpha}(j)$. To derive the first order consitions for firms optimization problem we write Lagrangian for the firm $j$ in the non-traded sector as:

$$
L=\left(W_{t} H_{N, t}(j)+R_{N, t} K_{N, t}(j)\right)+\lambda_{t}^{f}\left(Y_{N, t}(j)-A_{N} K_{N, t}^{\alpha}(j) H_{N, t}^{1-\alpha}(j)\right)
$$

so the first order conditions are:

$$
\begin{gathered}
\frac{\partial L}{\partial H_{t}(j)}=W_{t}-\lambda_{t}^{f} A_{N}(1-\alpha) K_{N, t}^{\alpha}(j) H_{N, t}^{-\alpha}(j)=0 \\
\frac{\partial L}{\partial K_{t}(j)}=R_{N, t}-\lambda_{t}^{f} A_{N} \alpha K_{N, t}^{\alpha-1}(j) H_{N, t}^{1-\alpha}(j)=0 \\
\frac{\partial L}{\partial \lambda_{t}^{f}}=Y_{N, t}-A_{N} K_{N, t}^{\alpha}(j) H_{N, t}^{1-\alpha}(j)=0
\end{gathered}
$$

The lagrangian multiplier on the constraint is interpretable as nominal marginal cost, so $\lambda_{t}^{f}=M C_{N, t}(j)$, and (7.1)-(7.3) correspond to the following:

$$
W_{t}=M C_{N, t}(j)(1-\alpha) \frac{Y_{N, t}(j)}{H_{N, t}(j)}
$$




$$
\begin{gathered}
R_{N, t}=M C_{N, t}(j) \alpha \frac{Y_{N, t}(j)}{K_{N, t}(j)} \\
Y_{N, t}(j)=A_{N} K_{N, t}^{\alpha}(j) H_{N, t}^{1-\alpha}(j)
\end{gathered}
$$

In the traded sector we assume perfect competition and flexible prices, so the cost of unit of production in that sector $M C_{T, t}=P_{T, t}$, such as the counterpart of equations (7.4)-(7.6) in traded sector is:

$$
\begin{gathered}
W_{t}=P_{T, t}(1-\gamma) \frac{Y_{T, t}}{H_{T, t}} \\
R_{T, t}=P_{T, t} \gamma \frac{Y_{T, t}}{K_{T, t}} \\
Y_{T, t}=A_{T} K_{T, t}^{\gamma} H_{T, t}^{1-\gamma}
\end{gathered}
$$

\subsection{Price setting by non-traded goods firms}

Firms in the non-traded sector set their prices as monopolistic competitors. Pricing behavior is taken as in Rotemberg and Woodford (1997) and Steinsson (2003). We use Calvo (1983) sticky price specification and assume that the firm $j$ changes its price with probability $\left(1-\theta_{N}\right)$. That is, each period there is a constant probability $\left(1-\theta_{N}\right)$ that the firm will be able to change its price, independent of past history ${ }^{25}$. We also assume that if prices are not reset, the old price is adjusted by a steady state inflation factor:

$$
\Pi_{N, t}=P_{N, t} / P_{N, t-1}
$$

Hence, even if the firm is not allowed to change its price, the latter grows at the same rate as trend inflation.

\footnotetext{
${ }^{25}$ Hence, the average time over which a price is fixed is given by $\left(1-\theta_{N}\right) 1+\theta_{N}\left(1-\theta_{N}\right) 2+\ldots+\theta_{N}^{i-1}\left(1-\theta_{N}\right) i+\ldots=$ $=\left(1-\theta_{N}\right) \sum_{i=0}^{\infty} i \theta_{N}^{i-1}=1 /\left(1-\theta_{N}\right)$. Thus, for example, with $\theta_{N}=0.75$ in a quaterly model, prices are fixed on average for a year.
} 
Those who re-set a new price (with probability $1-\theta_{N}$ ), are split into backward-looking and forward-looking firms, in proportion $\omega$, such that the aggregate index of prices set by the firms is

$$
P_{N, t}^{r}=\left[(1-\omega)\left(P_{N, t}^{F}\right)^{1-\lambda}+\omega\left(P_{N, t}^{B}\right)^{1-\lambda}\right]^{\frac{1}{1-\lambda}}
$$

Backward-looking firms set their prices according to the rule of thumb:

$$
P_{N, t}^{B}=P_{N, t-1}^{r} \Pi_{N, t-1}\left(\frac{Y_{N, t-1}}{Y_{N, t-1}^{n}}\right)^{\vartheta}
$$

As in Galì and Gertler, this rule of thumb has the following features: (1) in a steady state equilibrium the rule is consistent with optimal behavior, that is $P_{N}^{B}=P_{N}^{F},(2)$ the price set in period $t$ depends only on information dated $t-1$ or earlier.

\subsubsection{Forward-looking price-setters}

The problem of the firm $j$ changing price at time $t$ consists of choosing price $P_{N, t}^{n e w}(j)$ to maximize:

$$
E_{t} \sum_{i=0}^{\infty} \theta_{N}^{i} \Phi_{t+i}\left[P_{N, t}^{n e w}(j) \Pi_{N}^{i} Y_{N, t+i}(j)-T C_{N, t+i}(j)\right]
$$

subject to the total demand it faces:

$$
Y_{N, t+i}(j)=\left(\frac{P_{N, t}^{n e w}(j)}{P_{N, t+i}} \Pi_{N}^{i}\right)^{-\lambda} Y_{N, t+i}
$$

and where $\Phi_{t+i}$ is an appropriate stochastic discount factor, $\theta_{N}^{i}$ is the probability that the price $P_{N, t}^{n e w}(j)$ set for good $j$ still holds $i$ periods ahead, and $T C_{N, t+i}(j)$ represents total (nominal) costs. The discount factor relates to the way how the households value their future consumption relative to the current consumption, and we define the discount factor as:

$$
\Phi_{t+i}=\beta^{i} \frac{\Lambda_{t+i}}{\Lambda_{t}}=\beta^{i} \frac{P_{t+i}^{-1} C_{t+i}^{-\sigma}}{P_{t}^{-1} C_{t}^{-\sigma}}
$$

Cost minimizing behavior of the firm in non-traded sector yields the following expression for the total costs: $T C_{N, t+i}(j)=P_{N, t+i} m c_{N, t+i} Y_{N, t+i}(j)$, where $m c_{N, t+i}=M C_{N t+i} / P_{N, t+i}$ represents real marginal costs.

The FOC of this maximization problem yields the following optimal price:

$$
P_{N, t}^{n e w}(j)=\frac{\lambda}{\lambda-1} \frac{E_{t} \sum_{i=0}^{\infty}\left(\theta_{N} \beta\right)^{i} \Lambda_{t+i}\left(P_{N, t}^{n e w}(j) \Pi_{N}^{i} / P_{N, t+i}\right)^{\lambda} P_{N, t+i} m c_{N, t+i} Y_{N, t+i}}{E_{t} \sum_{i=0}^{\infty}\left(\theta_{N} \beta \Pi\right)^{i} \Lambda_{t+i}\left(P_{N, t}^{n e w}(j) \Pi_{N}^{i} / P_{N, t+i}\right)^{\lambda} Y_{N, t+i}}
$$


From (7.15) it is clear that all firms that reset their prices in period $t$, set it at the same level, so $P_{N, t}^{n e w}(j)=P_{N, t}^{n e w}$, for all $j \in[0,1]$, and we could omit subscript $j$. If we define two new variables

$$
P_{N, t}^{1}=E_{t} \sum_{i=0}^{\infty}\left(\theta_{N} \beta\right)^{i} \Lambda_{t+i}\left(\frac{P_{N, t}^{n e w} \Pi_{N}^{i}}{P_{N, t+i}}\right)^{\lambda} P_{N, t+i} m c_{N, t+i} Y_{N, t+i}
$$

and

$$
P_{N, t}^{2}=E_{t} \sum_{i=0}^{\infty}\left(\theta_{N} \beta \Pi_{n}\right)^{i} \Lambda_{t+i}\left(\frac{P_{N, t}^{n e w} \Pi_{N}^{i}}{P_{N, t+i}}\right)^{\lambda} Y_{N, t+i}
$$

then (7.15) can be rewritten as:

$$
P_{N, t}^{n e w}=\frac{\lambda}{\lambda-1} \frac{P_{N, t}^{1}}{P_{N, t}^{2}}
$$

Both $P_{N, t}^{1}$ and $P_{N, t}^{2}$ can be expressed recursively that does away the use of infinite sums, such that:

$$
\begin{gathered}
P_{N, t}^{1}=\Lambda_{t}\left(\frac{P_{N, t}^{n e w}}{P_{N, t}}\right)^{-\lambda} P_{N, t} m c_{N, t} Y_{N, t}+\beta \theta_{N} E_{t} P_{N, t+1}^{1} \\
P_{N, t}^{2}=\Lambda_{t}\left(\frac{P_{N, t}^{n e w}}{P_{N, t}}\right)^{-\lambda} Y_{N, t}+\beta \theta_{N} \Pi_{N} E_{t} P_{N, t+1}^{2}
\end{gathered}
$$

Finally, it is necessary to note that the optimal price set by forward-looking firms $P_{N, t}^{F} \equiv$ $P_{N, t}^{n e w}$

To obtain formula for the price set by forward-looking firms, we log-linearize expressions (7.16)-(7.18):

$$
\begin{gathered}
\widehat{p}_{N, t}^{1}=\left(1-\beta \theta_{N}\right)\left(-\sigma \widehat{C}_{t}-\lambda \widehat{p}_{N, t}^{n e w}+\widehat{p}_{N, t}+\widehat{m c}_{N, t}+\widehat{Y}_{N, t}\right)+\beta \theta_{N} E_{t} \widehat{p}_{N, t+1}^{1} \\
\widehat{p}_{N, t}^{1}=\left(1-\beta \theta_{N}\right)\left(-\sigma \widehat{C}_{t}-\lambda \widehat{p}_{N, t}^{n e w}+\widehat{p}_{N, t}+\widehat{m c}_{N, t}+\widehat{Y}_{N, t}\right)+\beta \theta_{N} E_{t} \widehat{p}_{N, t+1}^{1} \\
\widehat{p}_{N, t}^{n e w}=\widehat{p}_{N, t}^{1}-\widehat{p}_{N, t}^{2}
\end{gathered}
$$

where $p_{N, t}^{\text {new }}=P_{N, t}^{n e w} / P_{N, t} ; \quad p_{N, t}^{1}=P_{N, t}^{1} ; \quad p_{N, t}^{2}=P_{N, t}^{2} P_{N, t}$. Substituting (7.21) and (7.22) into (7.23), we obtain the following formula for the forward-looking firms: 


$$
\widehat{p}_{N, t}^{F}=\left(1-\beta \theta_{N}\right) \widehat{m c}_{N, t}+\beta \theta_{N} \widehat{p}_{N, t+1}^{F}+\beta \theta_{N} \pi_{N, t+1}
$$

where we turn to the notation $\widehat{p}_{N, t}^{n e w} \equiv \widehat{p}_{N, t}^{F}$.

\subsubsection{Aggregate price in the non-traded sector}

The price index in the non-traded sector is given by:

$$
P_{N, t}=\left(\int_{0}^{1} P_{N, t}(j)^{1-\lambda} d j\right)^{1 /(1-\lambda)}
$$

which can be expressed as the average of all prices set $i$ periods ago (in period $t-i$ ) that still hold in period $t$ :

$$
P_{N, t}=\left(\sum_{i=0}^{\infty}\left(1-\theta_{N}\right) \theta_{N}^{i}\left(\Pi_{N}^{i} P_{N, t-i}^{r}\right)^{1-\lambda}\right)^{1 /(1-\lambda)}
$$

where $\left(1-\theta_{N}\right) \theta_{N}^{i}$ is the fraction of firms that last adjusted price $\left(P_{N, t-i}^{r}\right) i$ periods ago.

Using (7.11), expression in (7.26) can be rewritten recursively as:

$$
\begin{aligned}
P_{N, t} & =\left[\left(1-\theta_{N}\right)\left(P_{N, t}^{r}\right)^{1-\lambda}+\theta_{N}\left(\Pi_{N} P_{N, t-1}\right)^{1-\lambda}\right]^{\frac{1}{1-\lambda}}= \\
& =\left[\left(1-\theta_{N}\right)(1-\omega)\left(P_{N, t}^{F}\right)^{1-\lambda}+\left(1-\theta_{N}\right) \omega\left(P_{N, t}^{B}\right)^{1-\lambda}+\theta_{N}\left(\Pi_{N} P_{N, t-1}\right)^{1-\lambda}\right]^{\frac{1}{1-\lambda}}
\end{aligned}
$$

Linearization of equation above yields:

$$
\pi_{N, t}=\frac{1-\theta_{N}}{\theta_{N}}\left[(1-\omega) \widehat{p}_{N, t}^{F}+\omega \widehat{p}_{N, t}^{B}\right]
$$

where, as before, $\widehat{p}_{N, t}^{F}$ and $\widehat{p}_{N, t}^{B}$ denote percent deviations of $P_{N, t}^{F} / P_{N, t}$ and $P_{N, t}^{B} / P_{N, t}$ respectively, from their steady-state values of one.

\subsubsection{Rule of thumb price-setters and Phillips curve}

The rule of thumb price-setters use formula (7.12) to set the new price. The log-linearization of this equation straightforwardly yields:

$$
\widehat{p}_{N, t}^{B}=\widehat{p}_{N, t-1}^{r}+\pi_{N, t-1}-\pi_{N, t}+\delta \widehat{y}_{N, t-1}
$$


where the log-linearized version of the index of prices set at date $t-1\left(\widehat{p}_{N, t-1}^{r}\right)$ result of loglinearization of formula (7.11), and given by

$$
\widehat{p}_{N, t-1}^{r}=(1-\omega) \widehat{p}_{N, t-1}^{F}+\omega \widehat{p}_{N, t-1}^{N}
$$

and $\widehat{y}_{N, t}$ denotes percent deviation of $Y_{N, t} / Y_{N, t}^{n}$ from steady state value of one.

So, now we have equation (7.24) that determines the price set by forward-looking firms, equation (7.29) that determines the price set by backward-looking firms and equation (7.28), thus, by doing manipulations similar to Steinsson (2003) (A.1)-(A.6), we eliminate $\widehat{p}_{N, t-1}^{F}$ and $\widehat{p}_{N, t-1}^{N}$ and obtain the following specification of the Phillips curve:

$$
\begin{aligned}
\pi_{N, t}= & \frac{\theta_{N} \beta}{\theta_{N}+\omega\left(1+\theta_{N} \beta-\theta_{N}\right)} E_{t} \pi_{N, t+1}+\frac{\omega}{\theta_{N}+\omega\left(1+\theta_{N} \beta-\theta_{N}\right)} \pi_{N, t-1}+ \\
& +\frac{\omega \vartheta\left(1-\theta_{N}\right)}{\theta_{N}+\omega\left(1+\theta_{N} \beta-\theta_{N}\right)} \widehat{y}_{N, t-1}-\frac{\beta \theta_{N} \omega \vartheta\left(1-\theta_{N}\right)}{\theta_{N}+\omega\left(1+\theta_{N} \beta-\theta_{N}\right)} \widehat{y}_{N, t}+ \\
& +\frac{\left(1-\beta \theta_{N}\right)(1-\omega)\left(1-\theta_{N}\right)}{\theta_{N}+\omega\left(1+\theta_{N} \beta-\theta_{N}\right)} \widehat{m c}_{N, t}
\end{aligned}
$$

Note that when $\omega=0$ then the Phillips curve collapses to the standard forward-looking specification:

$$
\pi_{N, t}=\frac{\left(1-\beta \theta_{N}\right)\left(1-\theta_{N}\right)}{\theta_{N}} \widehat{m c}_{N, t}+\beta E_{t} \pi_{N, t+1}
$$

When $\omega=1$ then the Phillips curve takes the specification:

$$
\pi_{N, t}=\frac{\theta_{N} \beta}{1+\theta_{N} \beta} E_{t} \pi_{N, t+1}+\frac{1}{1+\theta_{N} \beta} \pi_{N, t-1}-\frac{1-\theta_{N}}{1+\theta_{N} \beta}\left[\beta \theta_{N} \vartheta \widehat{y}_{N, t}-\vartheta \widehat{y}_{N, t-1}\right]
$$

\subsection{Aggregation issue}

In this subsection we focus on issues of aggregation in the non-traded sector. From cost minimization problem considered in the previous subsection we get:

$$
\frac{W_{t}}{R_{N, t}}=\frac{1-\alpha}{\alpha} \frac{K_{N, t}(j)}{H_{N, t}(j)} \Rightarrow \frac{1-\alpha}{\alpha} K_{N, t}(j)=H_{N, t}(j) \frac{W_{t}}{R_{N, t}}
$$

Integrating second expression in (7.34) over all firms, and defining

$$
K_{N, t}=\int_{0}^{1} K_{N, t}(j) d j ; \quad H_{N, t}=\int_{0}^{1} H_{N, t}(j) d j ;
$$


we get

$$
\frac{K_{N, t}(j)}{H_{N, t}(j)}=\frac{K_{N, t}}{H_{N, t}}
$$

The production function for a given good $j$ therefore becomes ${ }^{26}$

$$
Y_{N, t}(j)=A_{N} H_{N, t}(j)\left(\frac{K_{N, t}}{H_{N, t}}\right)^{\alpha}
$$

which implies that aggregate supply in the non-traded sector is

$$
\int_{0}^{1} Y_{N, t}(j) d j=A_{N} K_{N, t}^{\alpha} H_{N, t}^{1-\alpha}
$$

The demand for each differentiated good $j$ is given by:

$$
Y_{N, t}^{D}(j)=\left(\frac{P_{N, t}(j)}{P_{N, t}}\right)^{-\lambda}\left\{C_{N, t}+a\left(\frac{P_{N, t}}{P_{t}}\right)^{-\rho}\left[\phi_{N, t} K_{N, t}+\phi_{T, t} K_{T, t}\right]\right\} \equiv\left(\frac{P_{N, t}(j)}{P_{N, t}}\right)^{-\lambda} Y_{N, t}^{D}
$$

so aggregate demand in the non-traded sector is given by:

$$
\int_{0}^{1} Y_{N, t}^{D}(j) d j=Y_{N, t}^{D} \int_{0}^{1}\left(\frac{P_{N, t}(j)}{P_{N, t}}\right)^{-\lambda} d j
$$

where

$$
\Delta_{t} \equiv \int_{0}^{1}\left(\frac{P_{N, t}(j)}{P_{N, t}}\right)^{-\lambda} d j
$$

is a measure of relative price dispersion in the non-traded good sector. The steady state value of the dispersion is unity, while off-steady state it always $\geq 1$, and rises with the variance of nontraded prices. As the equation (7.40) shows the higher variability of prices, given aggregate nontraded goods output, there will less aggregate consumption of the non-traded goods. Combining idendities (7.38) and (7.40), the overall non-traded goods market equilibrium equation is:

$$
A_{N} K_{N, t}^{\alpha} H_{N, t}^{1-\alpha}=\Delta_{t} Y_{N, t}^{D}
$$

where $Y_{N, t}^{D}$ stands for aggregate demand of non-traded goods in the economy. Note that the aggregation introduces an additional term that deal with distribution of prices of non-traded goods. However, as shown by Yun (1996), Erceg et. al. (2000) and Christiano et. al. (2001) that

\footnotetext{
${ }^{26}$ Note that $(7.37)$ in conjuncture with $(7.4)$ can be used to show that nominal marginal costs are identical across firms in the non-traded sector.
} 
term does not appear in the log-linear approximation of the aggregate constraint. We briefly summarize their argument here for the non-traded sector. For that, we define

$$
\bar{P}_{N, t} \equiv\left(\int_{0}^{1} P_{N, t}^{-\lambda}(j) d j\right)^{-1 / \lambda}
$$

so that dispersion can be re-written as:

$$
\Delta_{t}=\left(\frac{\bar{P}_{N, t}}{P_{N, t}}\right)^{-\lambda}
$$

As for the aggregate price level in the non-traded sector, this price aggregate admits a recursive representation

$$
\bar{P}_{N, t}=\left[\left(1-\theta_{N}\right)\left(P_{N, t}^{r}\right)^{-\lambda}+\theta_{N}\left(\Pi_{N} \bar{P}_{N, t-1}\right]^{-1 / \lambda}\right.
$$

It can be easily seen that dispersion does not appear in the log-linearized version of the model. Log-linearization of aggregate price level of the non-traded sector, and the aggregate price index given by (7.45) yields the following expressions:

$$
\begin{gathered}
\widehat{P}_{N, t}=\left(1-\theta_{N}\right) \widehat{P}_{N, t}^{r}+\theta_{N} \widehat{P}_{N, t-1} \\
\widehat{\bar{P}}_{N, t}=\left(1-\theta_{N}\right) \widehat{P}_{N, t}^{r}+\theta_{N} \widehat{\bar{P}}_{N, t-1}
\end{gathered}
$$

while the log-linearized version of the price dispersion $\Delta_{t}$ is

$$
\widehat{\Delta}_{t}=\lambda\left(\widehat{P}_{N, t}-\widehat{\bar{P}}_{N, t}\right)
$$

So, substracting expression (7.46) from (7.47), and using expression in (7.48), we get that

$$
\widehat{\Delta}_{t}=\theta_{N} \widehat{\Delta}_{t-1}
$$

implying that if the economy is started from its steady state level, $\widehat{\Delta}_{t}=0$ for all $t$, which we will consider hereafter. 